
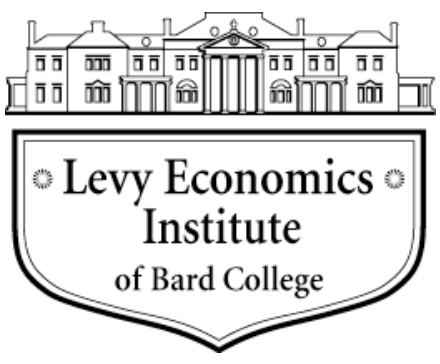

Working Paper No. 767

\title{
Germany and the Euroland Crisis: The Making of a Vulnerable Haven
}

by

\author{
Jörg Bibow* \\ Levy Economics Institute of Bard College
}

June 2013

\begin{abstract}
* I thank Jesse Hurwitz for his valuable research assistance as well as comments. I thank the participants at the "Euro Crisis" conference, held at the Universidad del País Vasco, Bilbao, Spain, on 14 December, for their responses to my presentation, and I thank Sergio Rossi, Andrea Terzi, and Yanis Varoufakis for their comments on an earlier draft. I also thank various staff at Destatis and the statistics department of the Deutsche Bundesbank for their helpful information services.
\end{abstract}

The Levy Economics Institute Working Paper Collection presents research in progress by Levy Institute scholars and conference participants. The purpose of the series is to disseminate ideas to and elicit comments from academics and professionals.

Levy Economics Institute of Bard College, founded in 1986, is a nonprofit, nonpartisan, independently funded research organization devoted to public service. Through scholarship and economic research it generates viable, effective public policy responses to important economic problems that profoundly affect the quality of life in the United States and abroad.

\author{
Levy Economics Institute \\ P.O. Box 5000 \\ Annandale-on-Hudson, NY 12504-5000 \\ http://www.levyinstitute.org
}

Copyright (C) Levy Economics Institute 2013 All rights reserved

ISSN 1547-366X 


\begin{abstract}
This paper investigates Germany's vulnerability to the ongoing Euroland crisis. In 2010-11, Germany experienced a strong rebound from the global financial crisis of 2008-09. The Euroland crisis then meant record low interest rates and a depressed euro that boosted German extra-area exports. But the crisis that started in Euroland's so-called periphery has meanwhile reached the core. With pro-euro sentiments dwindling fast across the European Union (EU), the future of the euro remains uncertain no matter what European Central Bank President Mario Draghi may promise. Germany's “safe haven” status may turn out to be a double-edged sword. In case of a euro breakup, swift appreciation of the new deutschmark would abruptly worsen German competitiveness and the German economy would crater as a result. Additional wealth losses on Germany's international investment position would also loom. Appreciating Germany's own vulnerability to the euro crisis should help the German authorities to understand that their policy prescriptions are anything but in Germany's own best interest, which is also good for the authorities in euro partner countries to recognize. Germany is bound to catch up with the reality that it is very vulnerable to the enormous wreckage and unnecessary hardship German-style policies are causing across Europe. The EU, most likely under French leadership, will have to convince Germany to embark on a fundamental policy course change, or else call an ugly end to the euro disaster.
\end{abstract}

Keywords: Euro; Monetary Union; Banking Crisis; Balance-of-Payments Crisis; Competitiveness Imbalances; Fiscal Transfers; Bailouts; Austerity; Euro Breakup

JEL Classifications: E42, E52, E58, E65, F36, G01 


\section{INTRODUCTION}

This paper investigates Germany's vulnerability to the ongoing Euroland crisis. So far crisis hardship has been concentrated in euro crisis countries while Germany has fared well during the crisis, or so it seems. In 2010-11 Germany experienced a strong rebound from the global financial crisis of 2008-9. The Euroland crisis then meant record low interest rates - owing to Germany's "safe haven" status - and a depressed euro that has boosted German extra-area exports. But the crisis that started in Euroland's so-called periphery has meanwhile reached the core. The French model of domestic demand driven growth unraveled in 2011 and the German economy stalled in the course of 2012. With pro-euro sentiments dwindling fast across the EU, the future of the euro remains uncertain no matter what European Central Bank (ECB) President Mario Draghi may promise. And Germany's safe haven status may turn out to be a doubleedged sword. For in the case of a euro breakup swift appreciation of the new deutschmark would abruptly worsen German competitiveness. Not only would the German economy crater as a result. Looming wealth losses on Germany's international investment position (IIP) are an additional vulnerability. Euroland policymaking essentially follows German recipes, today more than ever. Appreciating Germany's own vulnerability to the euro crisis should help the German authorities to understand that their policy prescriptions are anything but in Germany's own best interest, which is also good to recognize for the authorities in euro partner countries. Germany is bound to catch up with the reality that it is very vulnerable to the enormous wreckage and unnecessary hardship German-style policies are causing across Europe. The European Union (EU), most likely under French leadership, will have to convince Germany to embark on a fundamental policy course change, or else to call an ugly end to the euro disaster.

The analysis starts in section 2 with a review of Germany's current account position since WWII, highlighting how and why German surpluses ballooned under the euro. Analyzing Germany's international investment position (IIP) since WWII, section 3 highlights that, while Germany's creditor position has surged under the euro, huge valuation losses have left a big hole in its IIP. Sections 4 and 5 then attempt to identify where German exposures to financial risks may be concentrated by analyzing available data on financial flows and sectoral balance sheets, respectively. Section 6 assesses the main sources of Germany's vulnerability to developments in Euroland, while section 7 discusses the depressing reality that Euroland has yet 
to properly resolve the ongoing crisis and that continued crisis mismanagement is further magnifying the collateral damage so far endured. Section 8 concludes.

\section{GERMANY'S NOTORIOUS CURRENT ACCOUNT SURPLUSES BALLOONED UNDER THE EURO}

After suffering a balance of payments crisis in the early post-war reconstruction phase West Germany and later All-Germany have run sizeable current account surpluses for most of the time. Current account deficits were rarer and far more limited in size. Germany's current account surplus position grew largest under the euro regime and at seven percent of GDP stays very high today by international standards (see Figure 1).

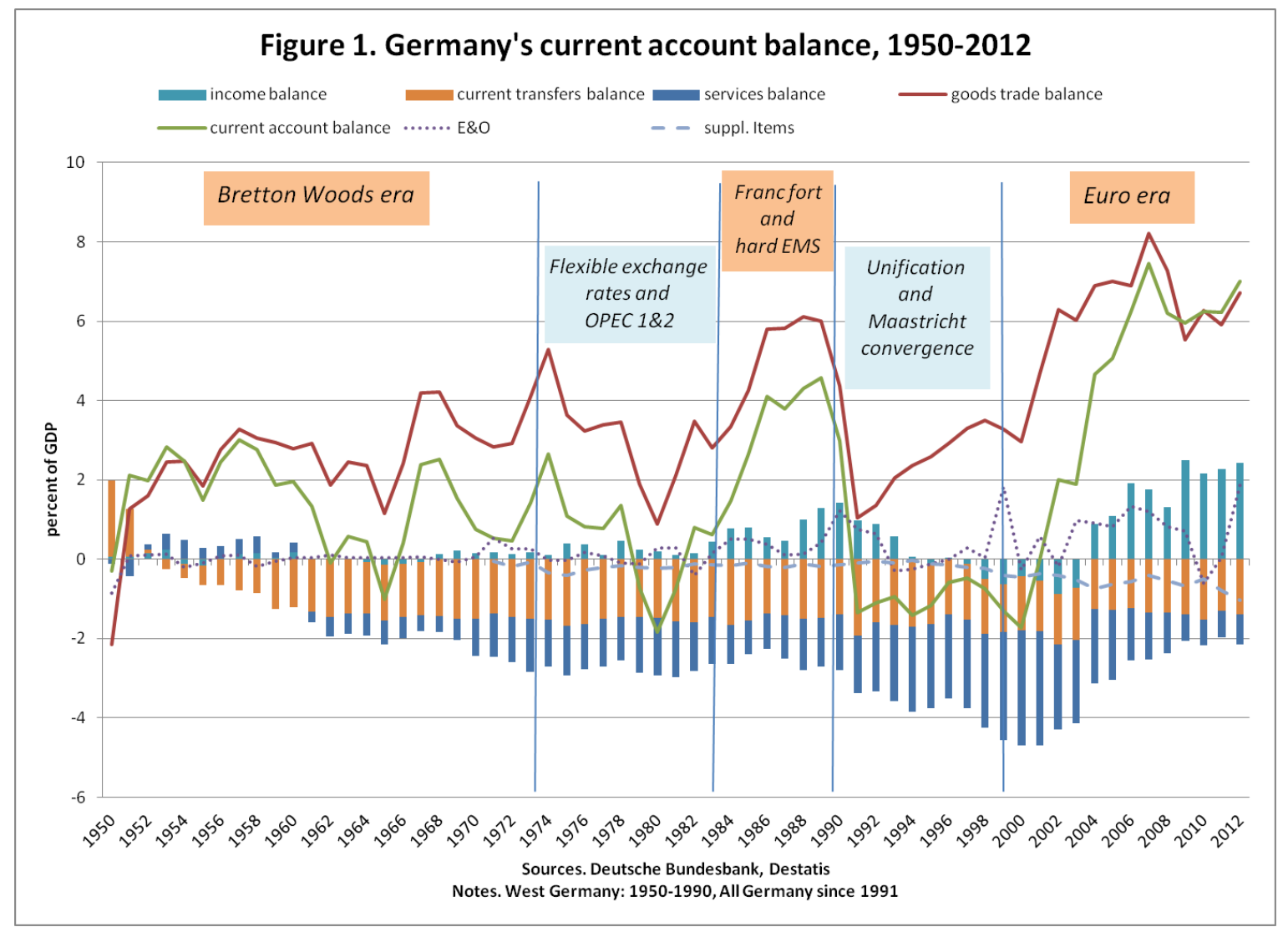

The German balance of payments crisis of 1950 arose in the context of the Korean War and surging global inflation, events which soon proved a boon toward reestablishing Germany's traditional role as a capital goods exporter. In fact, trade surpluses emerged in 1952 as a key engine behind the "economic miracle" of the 1950s; in the early years of which West Germany 
also benefited from Marshall Plan aid (Wallich 1955). Following a first deutschmark revaluation in 1961 West Germany at first experienced shrinking trade surpluses and even a small current account deficit by 1965, but sizeable trade and current account surpluses soon returned in the second half of the 1960s. Despite further deutschmark revaluations in 1969 and again in late 1971 (as part of the Smithsonian Agreement) large and rising external surpluses lasted until 1973 (Wallich and Wilson 1979), when the trend finally reversed with the arrival of floating exchange rates in March 1973 and onset of the first oil crises of 1973-4. While West Germany's trade balance stayed in surplus all along, current account deficits arose in 1979-1981. This occurred as the second oil crisis of 1979-80 delivered another negative terms-of-trade shock while the U.S. dollar went through an episode of pronounced weakness. Dollar weakness boosted German interest in stabilizing intra-European exchange rates. For the first time since 1950 a deficit - rather than surplus - in the external position became an economic policy issue in West Germany (Bibow 2013b).

But the 1980s brought a fresh turnaround in the external position. Starting from a small deficit position, West Germany ran up record trade and current account surpluses in the course of the 1980s. In a way, the 1980s provided a first run of developments which were going to reemerge under the euro regime in the 2000s. In the first half of the 1980s, West German extraarea exports were propelled by a strong U.S. dollar, with the U.S. acting as the global growth locomotive under the Reagan administration. As the dollar reversed course in 1985, rising European exports (and declining oil prices) then provided a welcome offset in the second half of the 1980s. On the eve of German unification, West Germany had trade and current account surpluses of around five percent of GDP, largely concentrated in Europe.

German unification then rebalanced Europe as far as intra-regional competitiveness positions and trade relations were concerned. Domestic demand expansion, temporarily elevated cost rises, and deutschmark appreciation in the context of the Exchange Rate Mechanism (ERM) crises of 1992-93 largely resolved the continent's sizeable internal current account imbalances. Germany had a small (around one percent of GDP) current account deficit in the 1990s. The current account turnaround of the 1990s after record surpluses in the late 1980s reflected the legacy of a ruined East German economy rather than any lack of competitiveness of the West German economy though (Bibow 2005). 


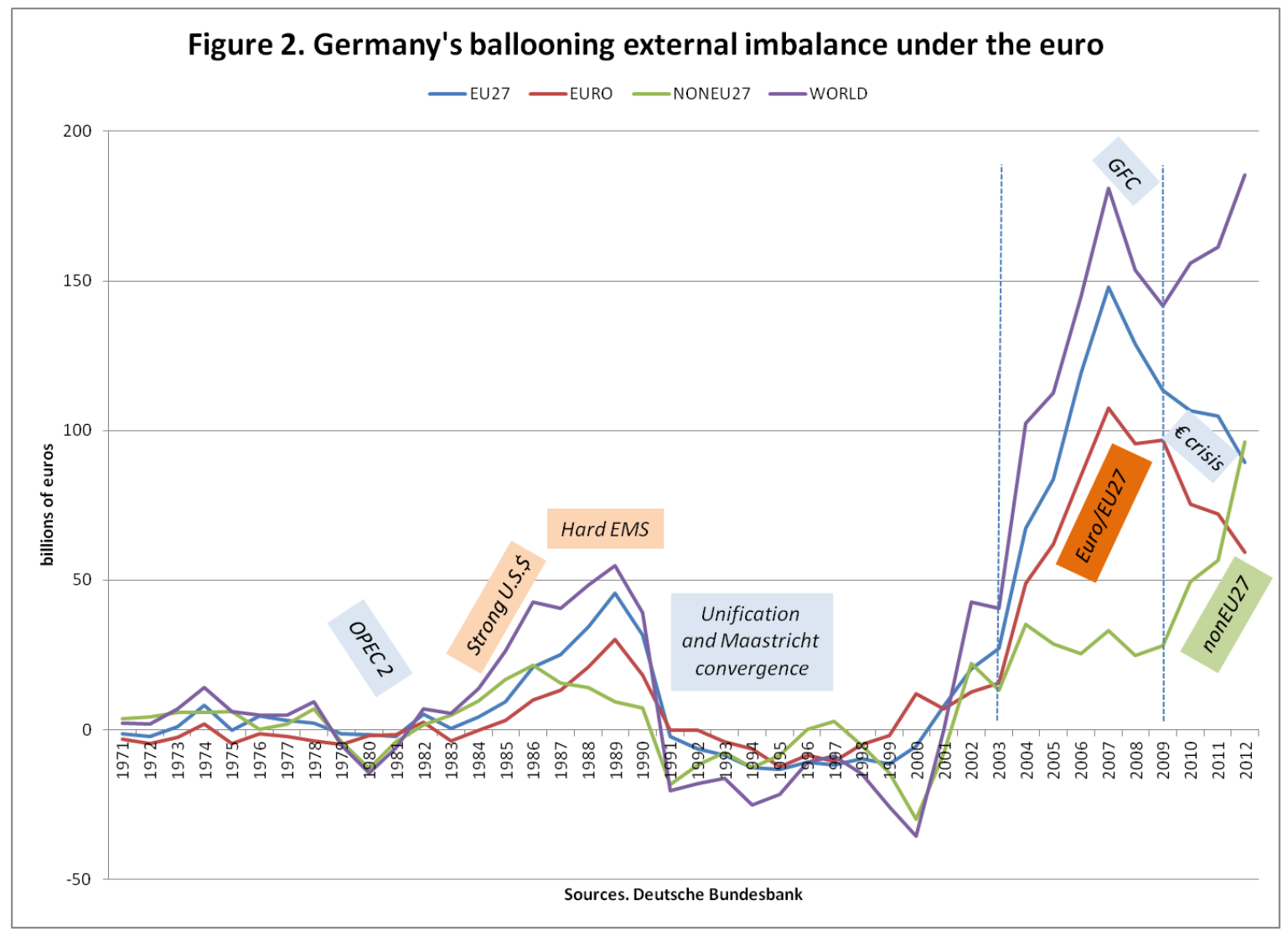

A new and far more remarkable shift in current account positions then occurred under the euro regime in the 2000s: as Germany's deficit of one percent of GDP at the start of Economic and Monetary Union (EMU) turned into a surplus of over seven percent by 2007 (see Figure 2). As earlier in the 1980s, there was a handover between global and regional forces featuring in this development. Initially, the improvement was mainly driven by rising surpluses vis-à-vis non Euroland members. Following the global slowdown of 2001 the global economy recovered strongly starting in 2002 as a record global boom gathered strength that lasted until the global financial crisis. While also partly reflecting energy and commodity prices more generally, it is noteworthy that Germany only received limited fresh stimulus from the global boom beyond 2003 until 2010. Instead, after having improved only very gradually since the mid-1990s, surpluses vis-à-vis Euroland members and the rest of the EU ballooned conspicuously in the years 2003 to 2007.

Germany was severely hit by the global financial crisis of 2008-09, but recovered swiftly on the back of resurging current account surpluses. Another changeover occurred at that point though: while the euro crisis and recession in Europe have squeezed Germany's surplus position 
within Europe, surpluses vis-à-vis non EU countries soared to fresh highs since 2010. Overall, Germany's current account surplus in 2012 of 185 billion euro even exceeded the pre-crisis record set in 2007. Slightly bigger than China's in U.S. dollar terms, as a percentage of GDP Germany's external imbalance still exceeds seven percent of GDP whereas China's has fallen sharply since the crisis from over 10 percent of GDP to 2.5 percent.

While a traditionally large surplus in merchandise trade is still the primary source of Germany's external imbalance, a notable decline in the traditionally negative service balance as well as a sizeable improvement in the income balance have occurred since the mid-2000s. Furthermore one may note here that errors and omissions were persistently positive and sizeable under the euro (as in the 1980s), which suggests that either actual current account surpluses may have been even larger or net financial outflows smaller than recorded. Finally, the rise in "supplementary items" (as a net deduction) since the 2000s is largely a reflection of the growing prominence of international (but not cross-border) gas and electricity trading (see Statistisches Bundesamt 2013a, b).

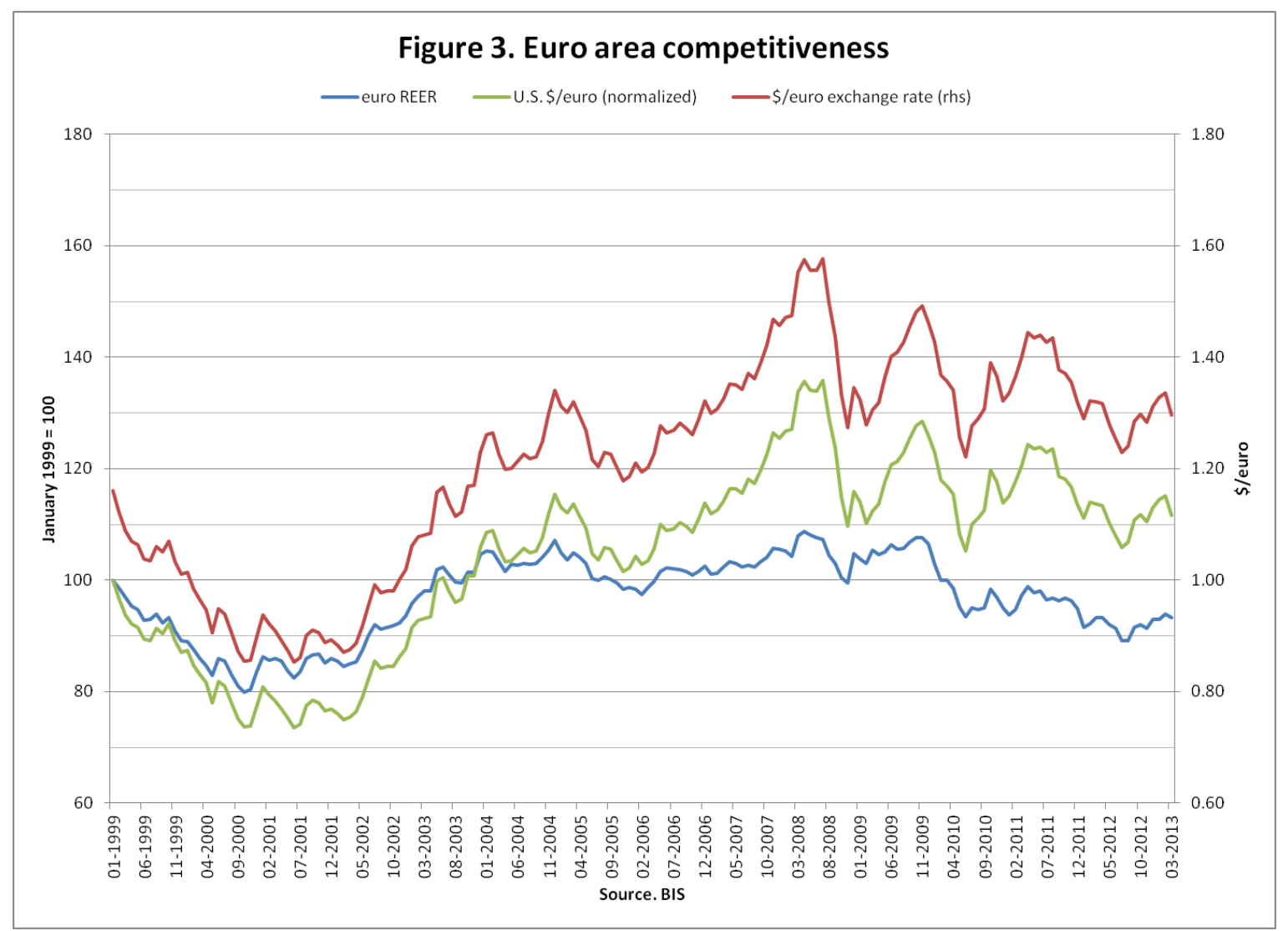


Apart from marked GDP growth differentials, the euro exchange rate largely explains the current account picture vis-à-vis non EU countries. The euro started appreciating strongly in 2002 in real effective terms and especially vis-à-vis the U.S. dollar. Euro strength cut Germany off from benefitting even more from the global boom in the mid-2000s. The euro crisis then had the convenient side-effect of prompting a sharp euro depreciation, which has helped Germany to recharge its export engine by re-coupling to global growth; ever more strongly shaped by China and other emerging market economies that are well-disposed towards German capital goods exports anyway. For instance, while Germany had a sizeable bilateral deficit vis-à-vis China prior to the global crisis, the bilateral position reached a near balance in 2012. Today, roughly half of Germany's external imbalance is vis-à-vis non EU-27 countries, and Germany's contribution to global current account imbalances easily exceeds 100 billion U.S. dollars. This issue will remain pertinent to the global community in view of the G-20 "Framework for Strong, Sustainable and Balanced Growth" in the future. ${ }^{1}$ In principle, the global issue can be straightforwardly addressed through an appropriate euro exchange rate - provided that the euro currency union is internally balanced.

Alas, the fact that the currency union is severely unbalanced internally represents a far more intricate problem to resolve. Intra-Euroland imbalances peaked in 2006-07 and have since declined significantly, at least as far as actual - as opposed to "structural" (or: full-employment)

\footnotetext{
${ }^{1}$ Prior to the global crisis the German authorities pleaded "not guilty" of contributing to global imbalances by arguing that the euro currency union was externally balanced overall while regional imbalances were judged irrelevant. Interviewing German Chancellor Angela Merkel at the time of the G20 summit in Seoul in November 2010, Barber, Peel, and Wiesmann (2010) quote Mrs. Merkel as even suggesting that in view of the European "single market" the whole European Union should be treated as a unity, leaving the calculation of trade imbalances on a country-by-country basis as "not meaningful". Since then the German authorities have become somewhat creative in justifying notorious German surpluses and rejecting anything that could contain them. For instance, in response to U.S. Secretary of the Treasury Tim Geithner's proposal to cap current account imbalances at four percent of GDP, Mrs. Merkel dismissed the whole idea of setting specific targets for maximum levels of balance of payments' surpluses and deficits as "too narrowly conceived". "I don't think much of quantified balance of payments targets," she said. "It is not just a question of exchange rates, but also a question of competitiveness." Much in contrast to German insistence on specific targets for maximum levels of budget deficits, finance minister Wolfgang Schäuble was equally dismissive of criticisms of Germany's trade surpluses, arguing that Germany's export success was not based on "exchange rate tricks" but on increased competitiveness (see Atkins 2010). Wiesmann and Pignal (2010) quote German economics minister Rainer Brüderle as deprecating U.S. calls for more government spending, asserting that Germany's recovery was "a non-Keynesian growth programme" in which fiscal discipline spurred private investment. Let me emphasize that there is of course nothing wrong with Germany as a successful exporter. Germany's notorious export surpluses are the issue (Bibow 2010).
} 
- imbalances are concerned (see Section 7 below). But even actual imbalances remain sizeable today and have come to pose a critical test to the euro's long-term survival.

As at the global level, current account imbalances within a regional currency union also require a financial counterpart. Prior to the euro crisis private capital flows were very forthcoming, pushing regional financial integration to new heights. But for euro crisis countries that source dried up as private capital flows suddenly stopped or even reversed. One challenge concerns the path towards a full rebalancing of the currency union and the required official financing flows that this process has come to depend on - the flow issue. Another challenge concerns the debt legacies which the buildup of current account imbalances has left in its trail the stock issue. This latter challenge continues to grow bigger for as long as imbalances persist even as the financing of those imbalances may have changed from private to official hands meanwhile. Moreover, the two challenges are actually strongly interrelated since addressing the flow issue by deflating debtor economies will tend to raise their indebtedness.

We will return to these two major challenges in Section 7 below, following the analysis of Germany's vulnerability to the euro crisis. Before, it is in order to briefly highlight here the key cause behind the intra-area imbalances that ushered the currency union into its existential and still unresolved crisis.

Essentially, a currency union is a commitment to a common inflation rate. And the ECB's definition of price stability as "below but close to 2 percent" attaches a number to that commitment, which provides a stability norm for wage trends. The "golden rule of currency union" says that national wage trends corrected for productivity (i.e. unit labor costs) cannot stray from this stability norm for long without causing imbalances. With nominal exchange rates gone, unit labor cost trends determine whether intra-area real exchange rates stay in balance. In actual fact, competitiveness positions diverged strongly and fatefully under the euro regime.

Conventional wisdom has it that today's crisis countries "lost competitiveness" due to excessive wage-price inflation. Unfortunately this view is missing the point by far. For Germany was the true outlier, although in the downward direction (see Figure 4). At close to 30 percent of area GDP, Germany is the largest economy in the currency union. As Europe converged to the 2-percent stability norm, Germany lastingly diverged from its own historical 2-percent stability norm under the euro regime. One consequence was that competitiveness positions inside the 
currency union ran seriously out of kilter and imbalances built up. Another consequence was that diverging wage trends also undermined the "one-size-fits-all" monetary policy, setting off an asymmetric shock. As wage restraint together with mindless austerity and structural labor market reform persistently depressed the "sick man of the euro's" domestic demand, the ECB's uniform nominal interest rate also meant relatively tighter financial conditions in Germany, magnifying divergence further, as the opposite would be the case in countries with aboveaverage inflation, such as booming and bubbling Spain and Ireland (Bibow 2005, 2006, 2012b; see also Flassbeck 2007, and Cesaratto 2011).

The outcome for the currency union, as far as internal competitiveness positions are concerned, was quite equivalent to a 20 percent plus deutschmark devaluation. The euro has of course ruled out that kind of "beggar-thy-neighbor" strategy - and its ultimate purpose was just that. But with exchange rates no longer available as a tool for swift rebalancing, intra-area imbalances will have to be resolved in the same way they built up: by reverse movements in relative unit-labor costs.

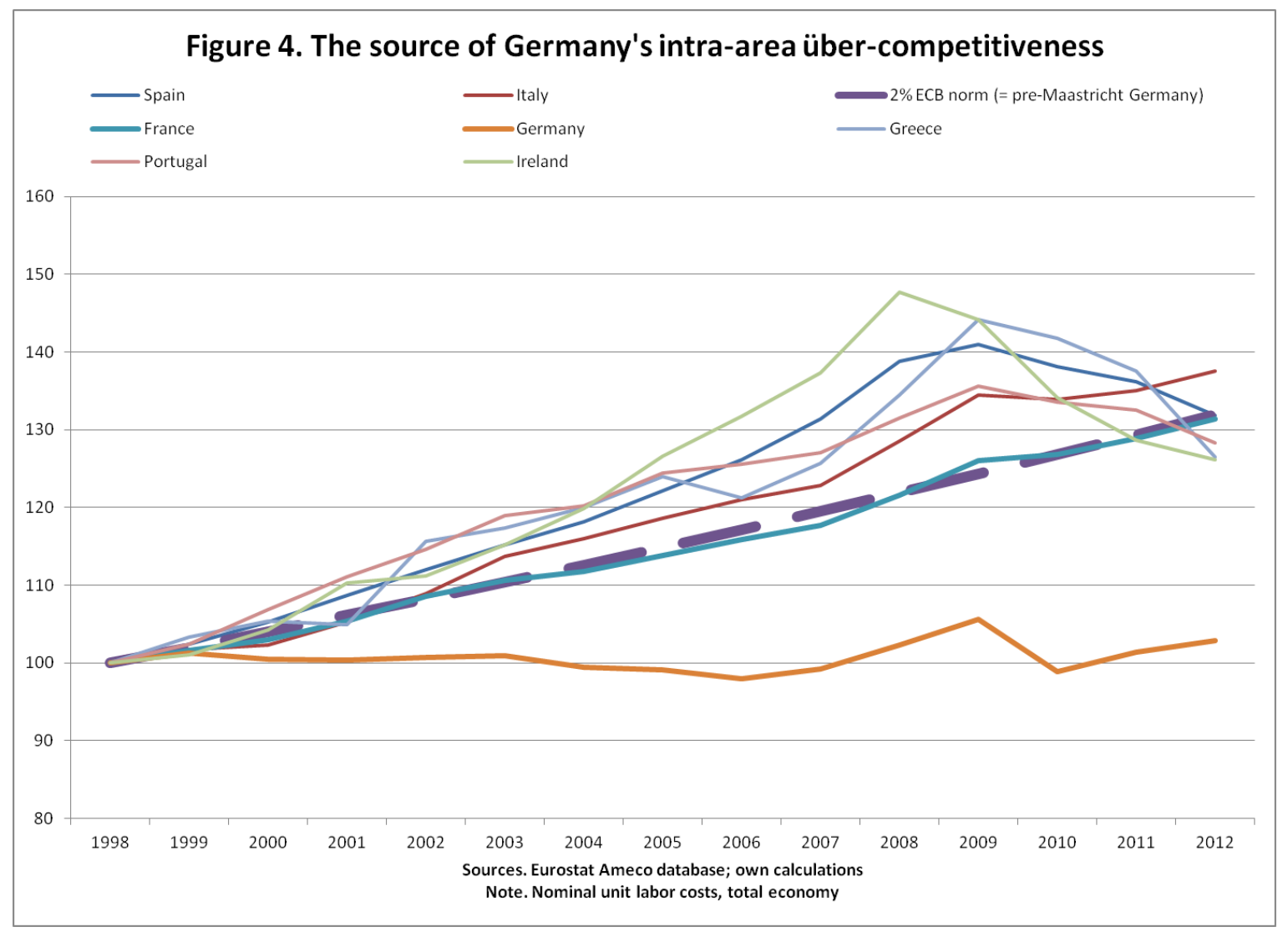


In principle, reversing unbalanced relative positions can be done in more than one way and, as already indicated above, choosing a deflationary path for debtor countries may be unwise. We will return to this issue in Section 6 below when we assess Germany's vulnerability to occurrences in indebted partner countries as the needed intra-area rebalancing is taking shape following Germany's "stability-oriented” policy dogma. The next section takes a look at Germany's international investment position.

\section{GERMANY'S INTERNATIONAL INVESTMENT POSITION AND VALUATION EFFECTS}

A country that runs persistent current account surpluses either pays off net foreign debts or accumulates net foreign assets. In sharp contrast to the war reparation debts that had challenged Germany in the aftermath of World War I and the Treaty of Versailles of 1919, the re-born (albeit divided) West Germany emerged from World War II with a very manageable external debt burden. Essentially, the new West German government started out with a clean balance sheet except for the debt instruments used to fill the holes in the banks' balance sheets owing to the currency reform of 1948 (“Ausgleichsforderungen") and external debt of around five percent of GDP as a result of the London Debt Agreement of 1953 (which halved West Germany's external debts). The latter were paid off gradually in subsequent decades as persistent current account surpluses were also accompanied by reserve accumulation on the Bundesbank's part, with currency reserves representing the bulk of West Germany's net international investment position, which turned positive in 1956 and then fluctuated around five percent of GDP until the early 1980 s. 


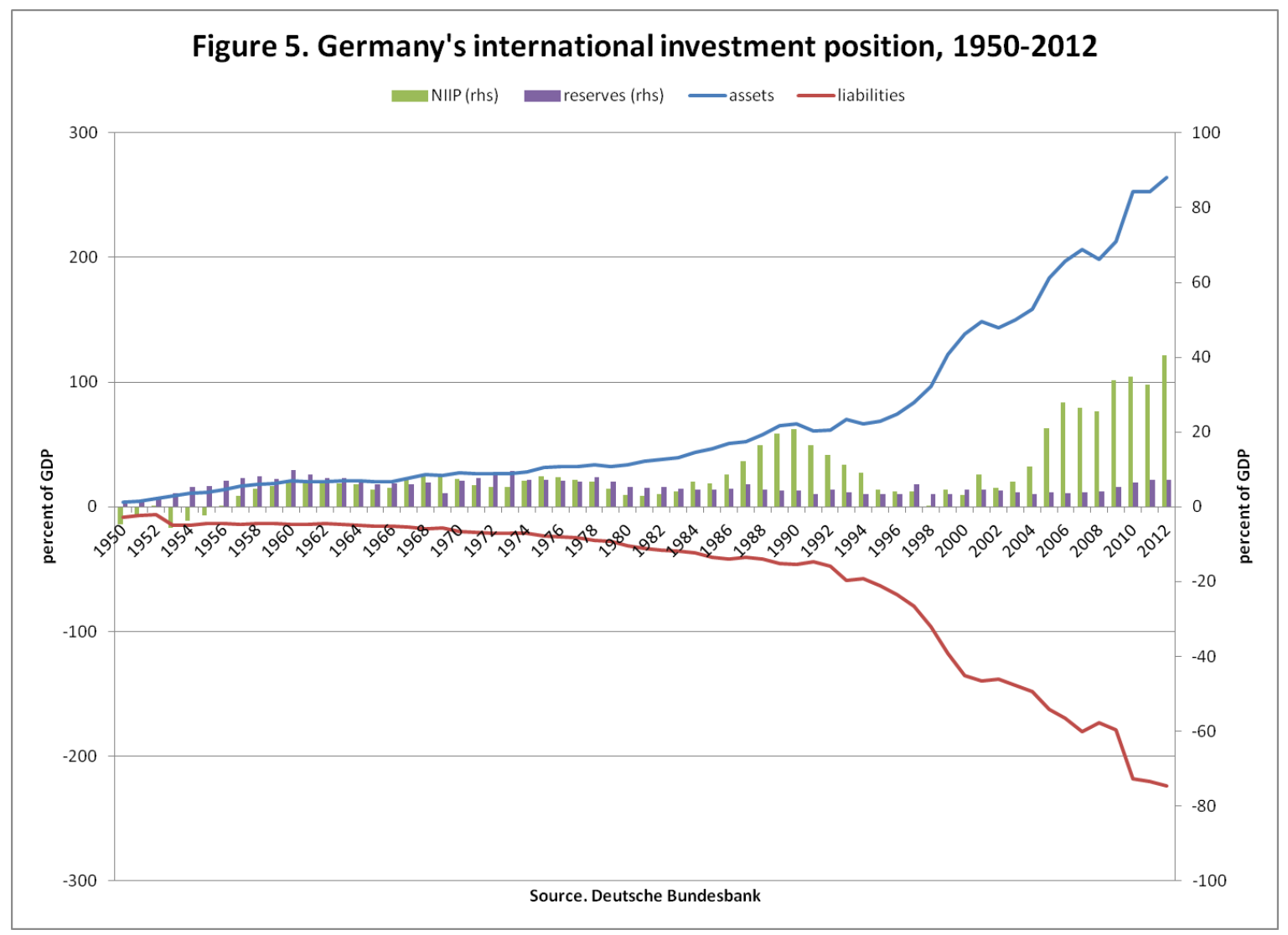

On the back of soaring current account surpluses West Germany first saw a more sizeable positive net international investment position (NIIP) emerging in the 1980s: net foreign assets - largely private by this time - peaked at 22 percent of GDP in 1989. Net foreign assets then melted away again gradually over the course of the 1990s as West Germany's external surplus of five percent of GDP had given way to an All-German external deficit of around one percent of GDP.

In line with the subsequent turnaround in the current account balance under the euro Germany's NIIP has seen a highly favorable evolution once more, with net foreign assets reaching 40 percent of GDP by 2012. Apart from the stark improvement in Germany's net position, Figure 5 also shows that gross cross-border holdings have truly taken a quantum leap since the introduction of the euro. Gross assets had stayed around 50-70 percent of GDP between the mid-1980s and mid-1990s, but surged beyond 200 percent of GDP by 2007, while gross liabilities reached 180 percent of GDP in that year. Germany's foreign assets were EUR 7 
trillion, foreign liabilities EUR 6 trillion, and net foreign assets of over EUR 1 trillion by the end of 2012 (see Figure 6). ${ }^{2}$

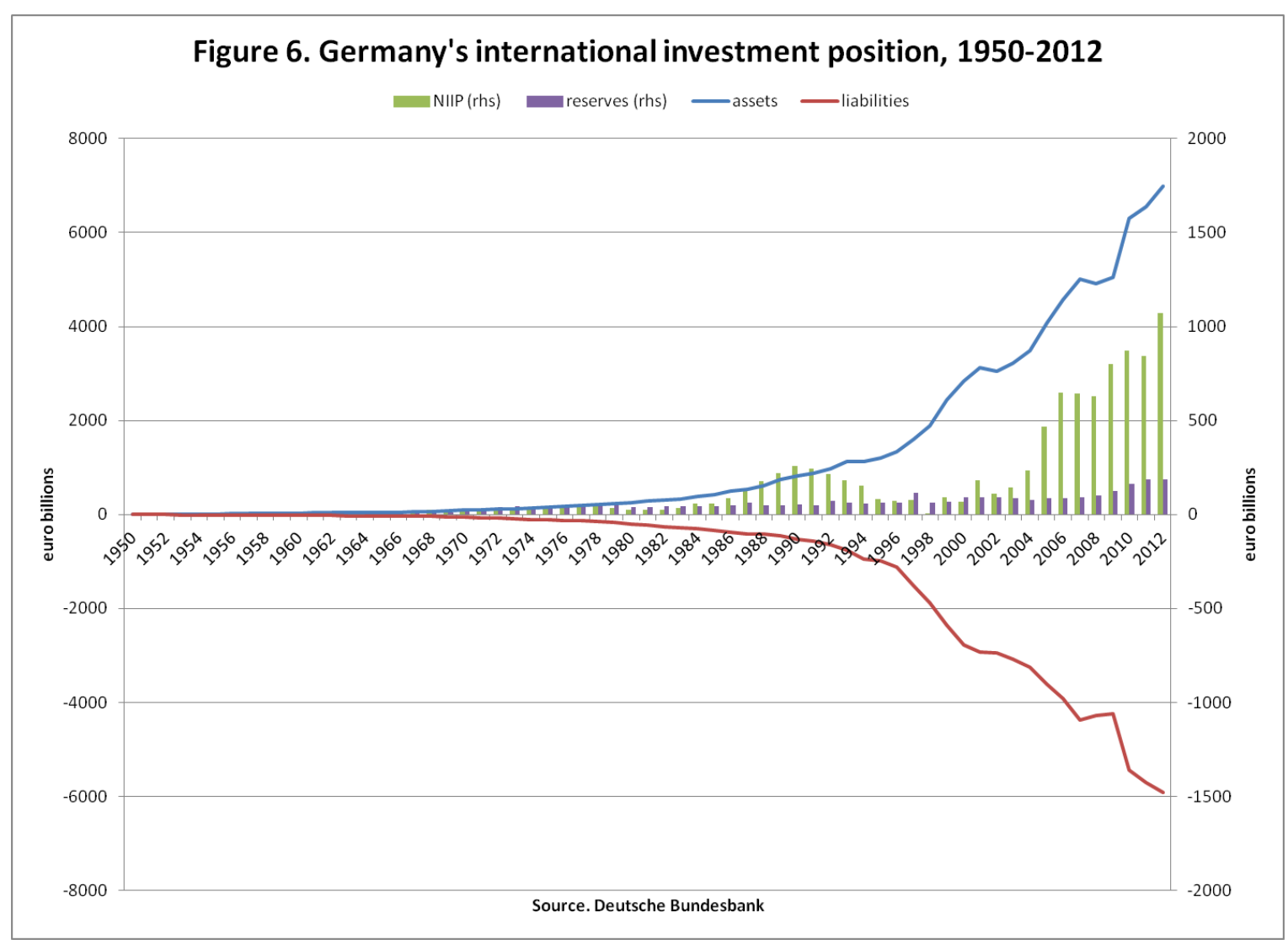

\footnotetext{
${ }^{2}$ Data for financial derivatives are only available since the final quarter of 2010. Their inclusion is largely responsible for the increase in foreign assets and liabilities since 2010, with little impact on the net position (see Figure 7).
} 


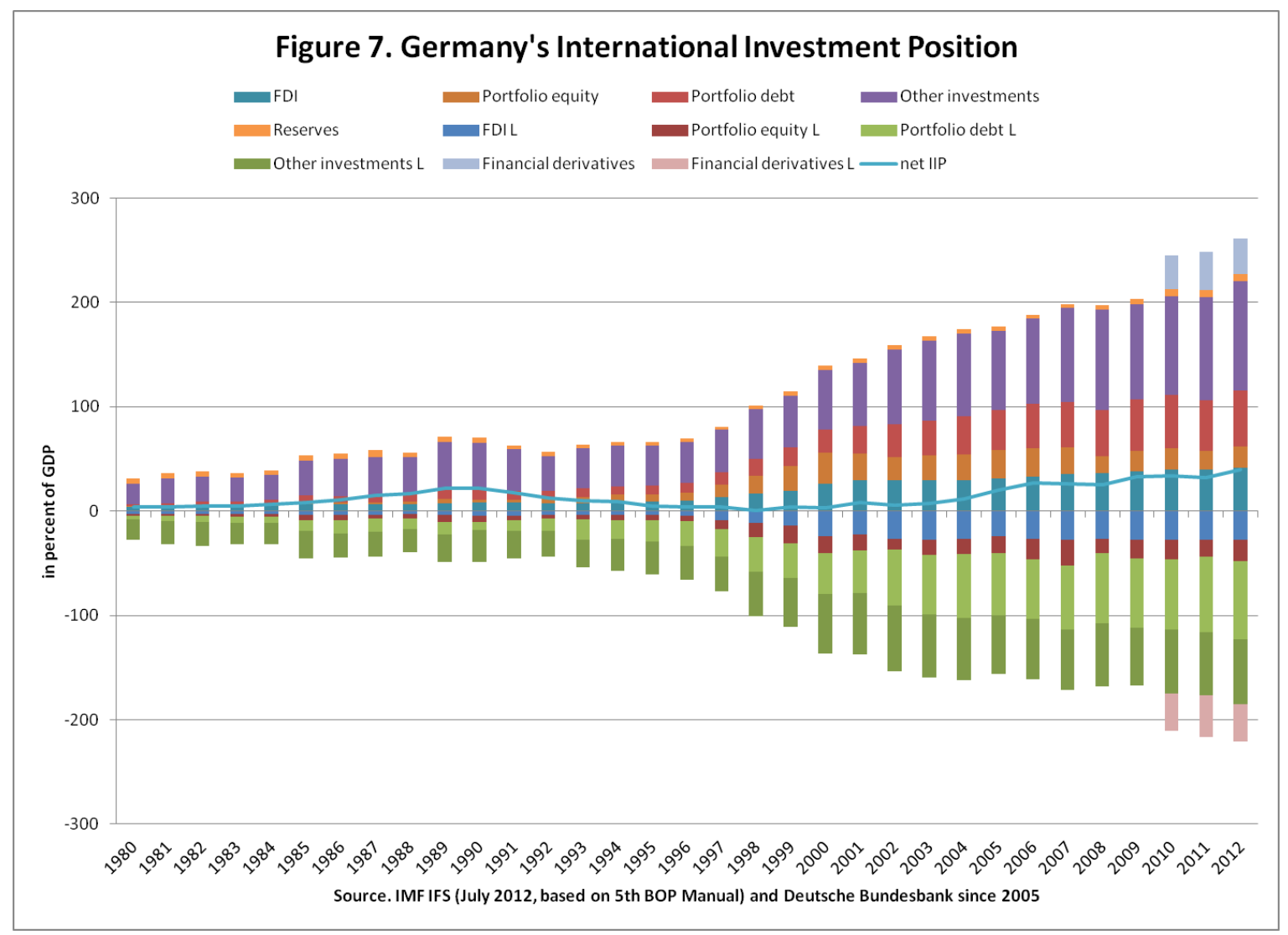

As to its composition, Figure 7 shows that the expansion of Germany's international investment position since the 1990s has been broad-based in all categories: foreign direct investment (FDI), portfolio investment, and other investment, although at diverse speeds and marked differences across assets and liabilities. ${ }^{3}$

\footnotetext{
${ }^{3}$ The IMF's International Financial Statistics switched to using the new $6^{\text {th }}$ Balance of Payments (BOP) Manual in August 2012. This resulted in an unfortunate data break since the new series have the disadvantage of missing the sectoral disaggregation in the "other investment" category, which is so central to the euro crisis and TARGET2 balances. Also, while the old time series based on the $5^{\text {th }}$ BOP Manual end with the year 2011, the new time series are only available since 2005 at this point.
} 


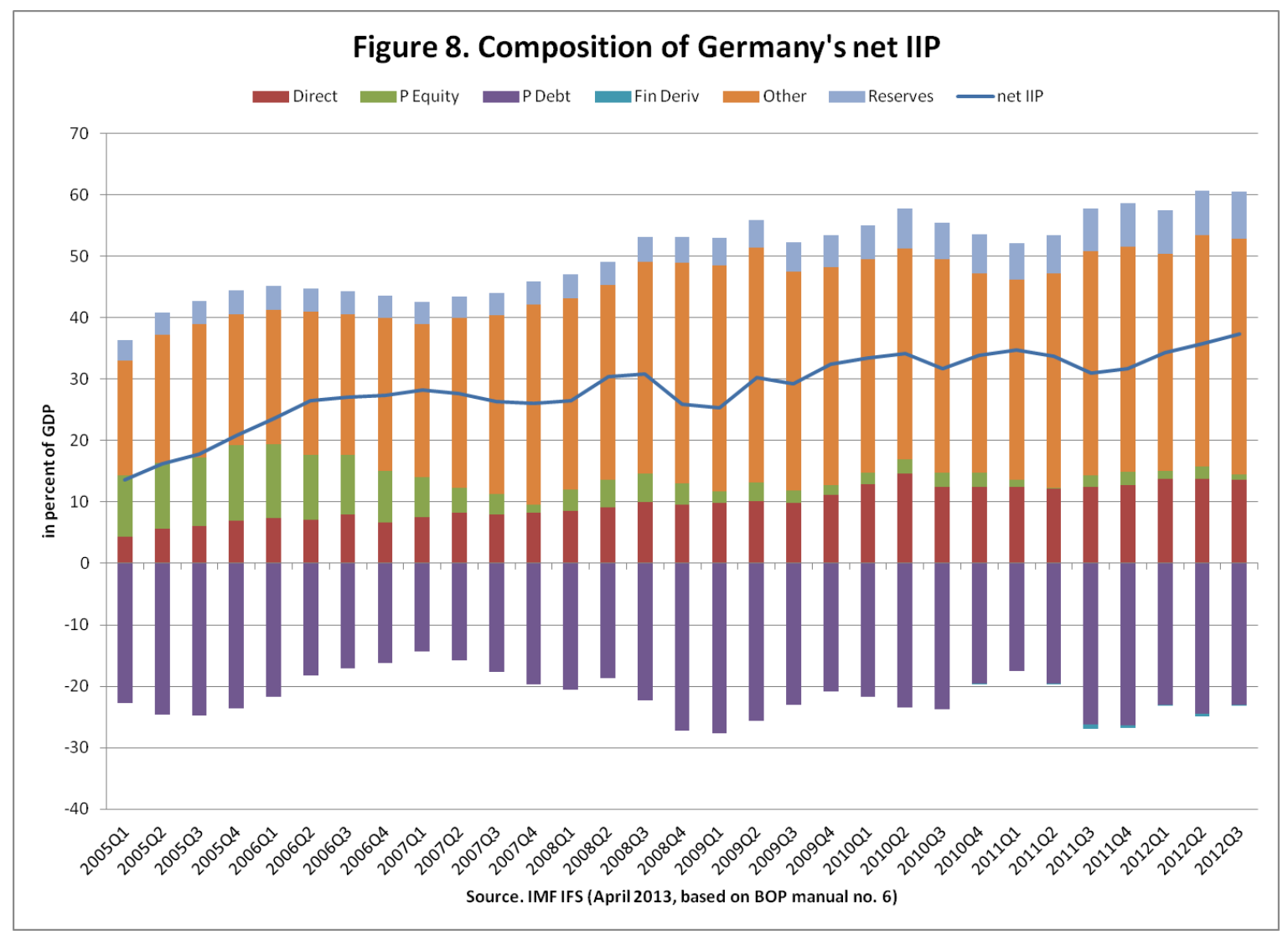

Seen on a net basis (see Figure 8), Germany has a portfolio debt net liability of around 20 percent of GDP that has been relatively steady over time, but FDI and portfolio equity net asset positions which together also come close to a 20 percent of GDP today; up from 9 percent in 1998. Reserve assets have risen from 3.5 percent of GDP to close to 7 percent since 2004, largely due to the increase in Germany's International Monetary Fund (IMF) reserve position and valuation gains owing to higher gold prices. But the primary feature of the buildup of a 40percent-of-GDP international creditor position from zero over this period is the surge in the “other investment” category (up from around 10 percent to 35 percent of GDP since 2004). 


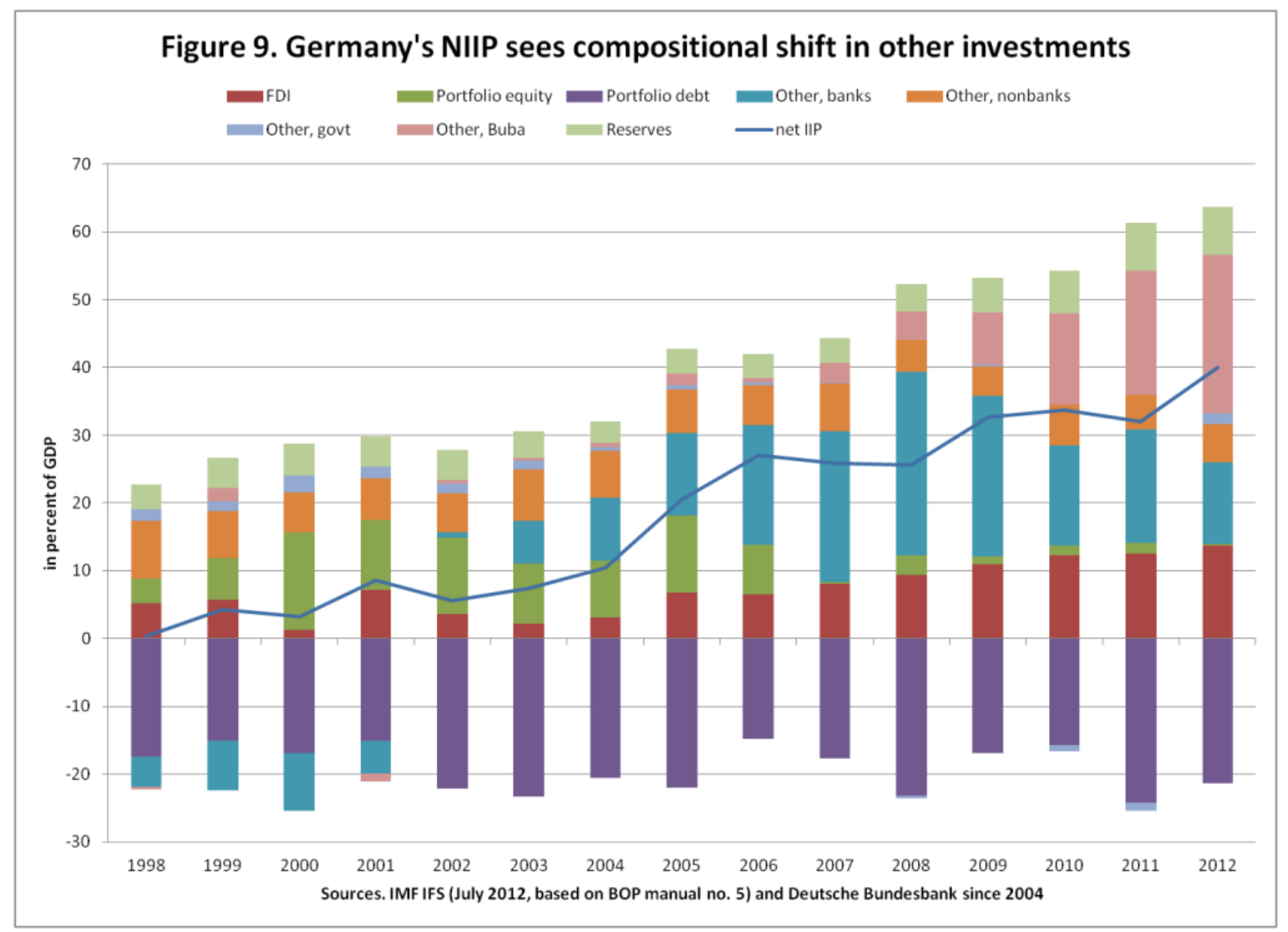

As Figure 9 shows, until 2009 especially other investment by banks surged, reversing an earlier net liability. Since its peak of close to 30 percent of GDP in late 2008, the banks' other investment net position has halved again though, a drastic shrinkage in German banks' international exposure that has been accompanied - and fully offset - by a conspicuous surge in the Bundesbank's other investment abroad. For the main the Bundesbank's other investment position consists of its infamous TARGET2 creditor balances at the ECB, which peaked at EUR 720 billion (27 percent of GDP) in October/November 2012 but have since declined by some EUR 100 billion (to around 23 percent of GDP). The role of TARGET2 imbalances will be further analyzed below in section 6 . 


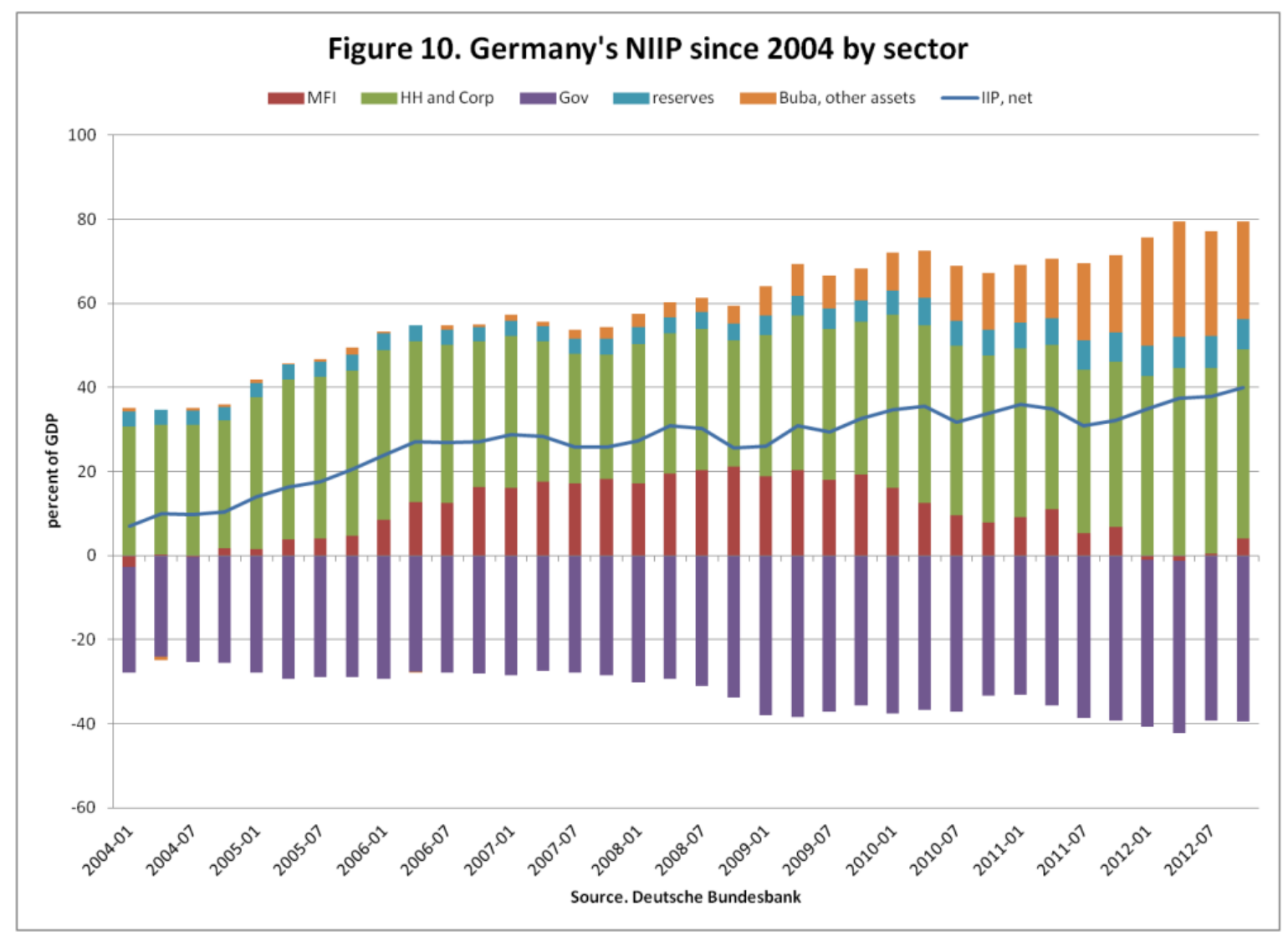

When viewed disaggregated by sector as shown in Figure 10, by the end of 2011, Germany's monetary financial institutions fully reversed their international exposure of 20 percent of GDP they had previously built up between 2005 and 2008. Some minor reengagement occurred in the course of 2012. The banks' pullback was mirrored by a corresponding rise in the Bundesbank's TARGET2 position. Also, Germany's public sector net foreign liability increased over this period from 30 to 40 percent of GDP, reflecting the rising attractiveness of Bunds to foreign public and private investors as "safe haven" assets. As Figure 11 shows, apart from retrenching their other investment, with short-term ones actually turning sharply negative on a net basis, there was a rise in the Monetary Financial Institutions' (MFIs') net portfolio investment liability too. ${ }^{4}$

\footnotetext{
${ }^{4}$ Cecchetti et al. (2012, p. 11) observe that banks located in Germany have "flipped from providing euros to banks in the rest of the world to absorbing euros from banks in the rest of the world ... This is an extraordinary development for a creditor country - that its banks become net recipients of home-currency funding from banks in the rest of the world. While there has been much discussion of retail investors shifting their deposits into banks in Germany, the bank-to-bank channel shows a shift of hundreds of billions of euros."
} 


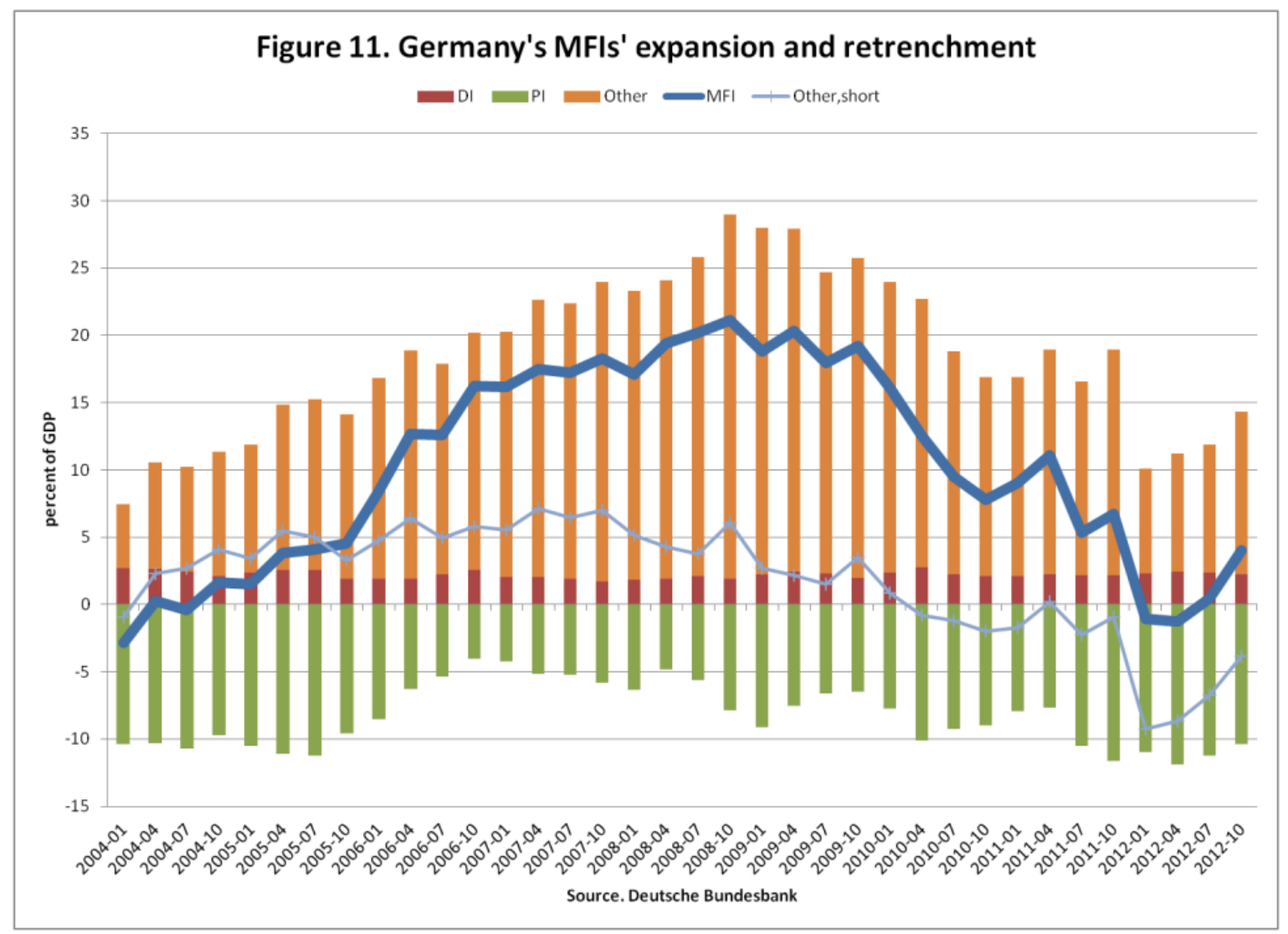

Apart from the Bundesbank's net foreign assets of around 30 percent of GDP (reserves plus TARGET2 credit balances), German households and corporations also have a large net foreign asset position, namely of some 45 percent of GDP by the end of 2012. And as Figure 12 shows, net exposures of households and corporations are concentrated in the portfolio debt investment category. 


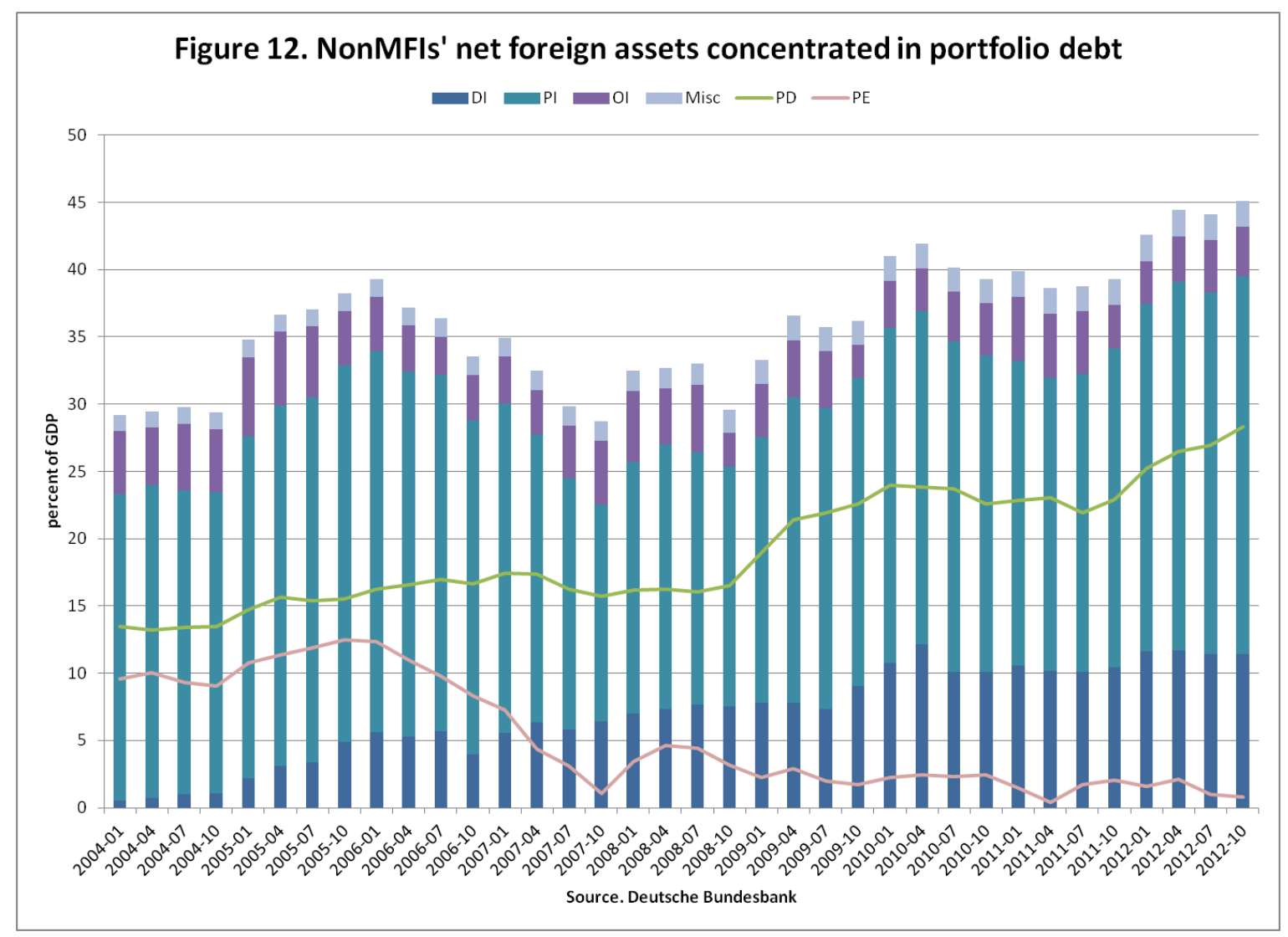

While Germany's NIIP surged under the euro, it is noteworthy that its actual improvement falls significantly short of Germany's cumulated current account surpluses over the same period. Compared to cumulated current account surpluses since 1980, cumulated negative valuation effects amounted to a whopping 21 percent of GDP by the end of 2011, falling slightly to 19 percent of GDP by the end of 2012. Given that the evolution of Germany's international investment position (IIP) featured valuation gains in the mid-2000s, the valuation losses experienced in recent crisis years actually peaked at almost 25 percent of GDP (see Figure 13).

Reviewing the period of 1999 until 2007 the Bundesbank (2008, p. 17) observed that "exchange rate changes have had a negative effect on the international investment position overall (EUR 144 billion). Owing to the trend appreciation of the euro, this reflects the accumulated losses relating to positions denominated in foreign currency which, because of the higher proportion of foreign currency on the asset side, have a negative impact on the net international investment position. ... By contrast, market prices - particularly developments on the share and bond markets - had a slightly positive effect in the period under review, albeit 
with major fluctuations in individual years (accumulated effect: EUR 25 billon). Market-price related haircuts were applied only at the beginning of the decade and in 2007. Last year alone, market price changes reduced the net international investment position by EUR 67 billion, in part because, in 2007, the share prices of German companies rose significantly more than those of foreign companies." The European Commission (2012) is reporting large overall valuation losses from the second half of 2007 through to 2011, arising from valuation losses on foreign assets and financial derivatives that were compounded by valuation increases in foreign liabilities but mitigated by valuation gains on foreign reserves. They note that "the largest part of these losses had already been realized in 2007-08, as a result of the implosion of the U.S. subprime mortgage debt market ... Germany was among the hardest hit due to its very high holdings of [asset-backed commercial paper]“ (European Commission 2012, p. 40). ${ }^{5}$

\footnotetext{
${ }^{5}$ Let me add that while Figure 13 shows sizeable valuation losses from 1985 through to 1998, which then reversed until 2006, Germany had also experienced valuation losses in the pre-1980 period, probably largely due to deutschmark appreciation vis-à-vis the U.S. dollar. The Bundesbank (2011) describes the influence of the newly established resolution agencies on Germany's balance of payment for 2010. These were the "Erste Abwicklungsanstalt" and the "FMS Wertmanagement", established by WestLB and Hypo Real Estate, respectively, based on the Financial Market Stabilization Development Act of 2009. See also IMF 2011.
} 


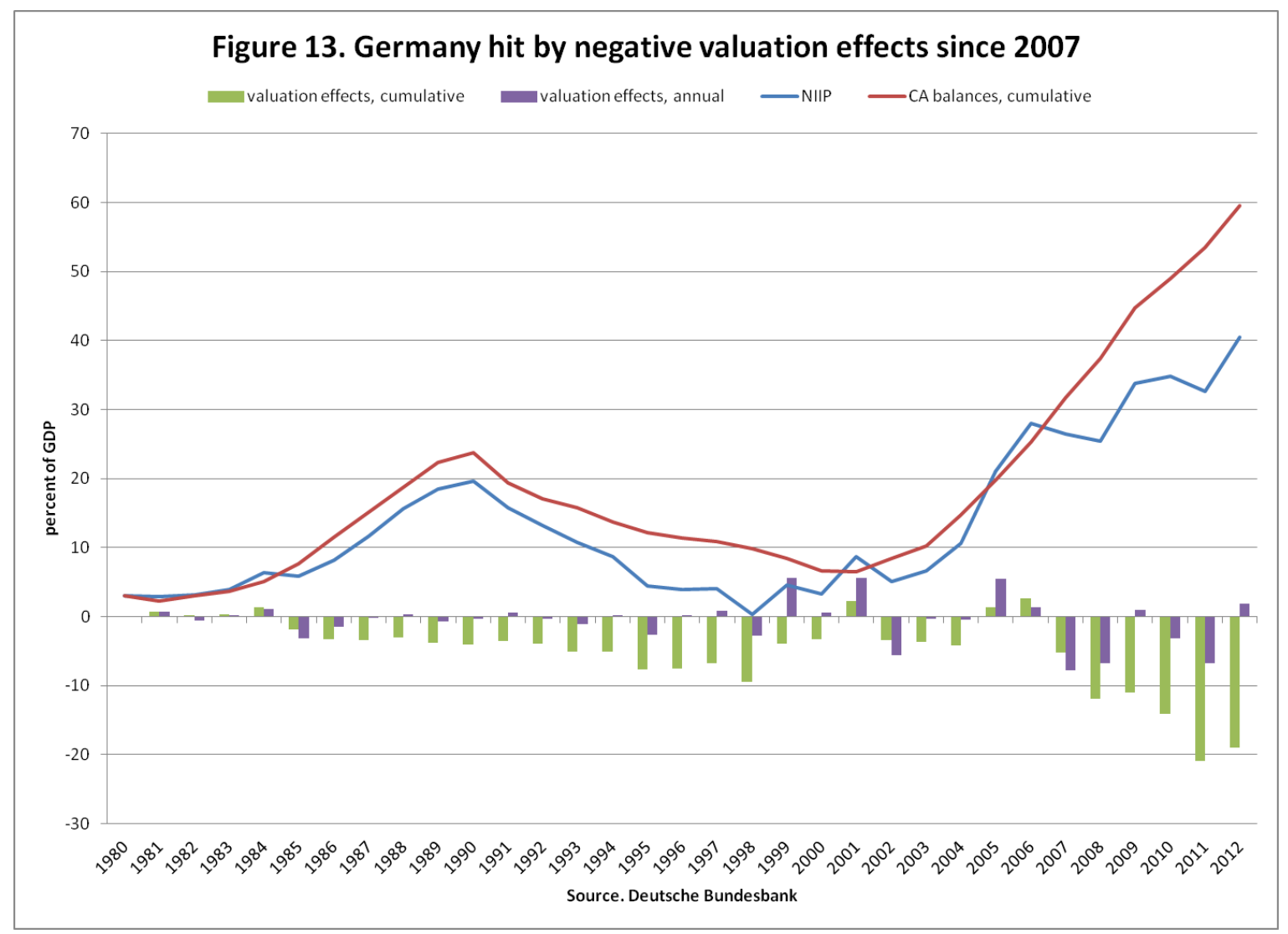

Cumulated financial flows since 1971 yield a hypothetical foreign asset position which at 8 trillion euro exceeds foreign assets recorded in Germany's international investment position (EUR 7 trillion) by even more. On the liability side flows and stocks seem to match up much more closely. Put differently, on the basis of cumulated financial flows Germany's hypothetical net foreign assets are estimated at EUR 1.8 trillion in 2012 as opposed to the actually recorded EUR 1 trillion. This even bigger gap is largely attributable to the systematic upward bias of “errors \& omissions" in Germany's balance of payments accounts mentioned above, a gap of close to EUR 290 billion euro since 1971 (EUR 230 billion since 1999). A smaller part owes to capital transfers. In any case, Germany seems to have suffered very substantial valuation losses over time on its net international investments - a thrashing that was concentrated in recent years. 


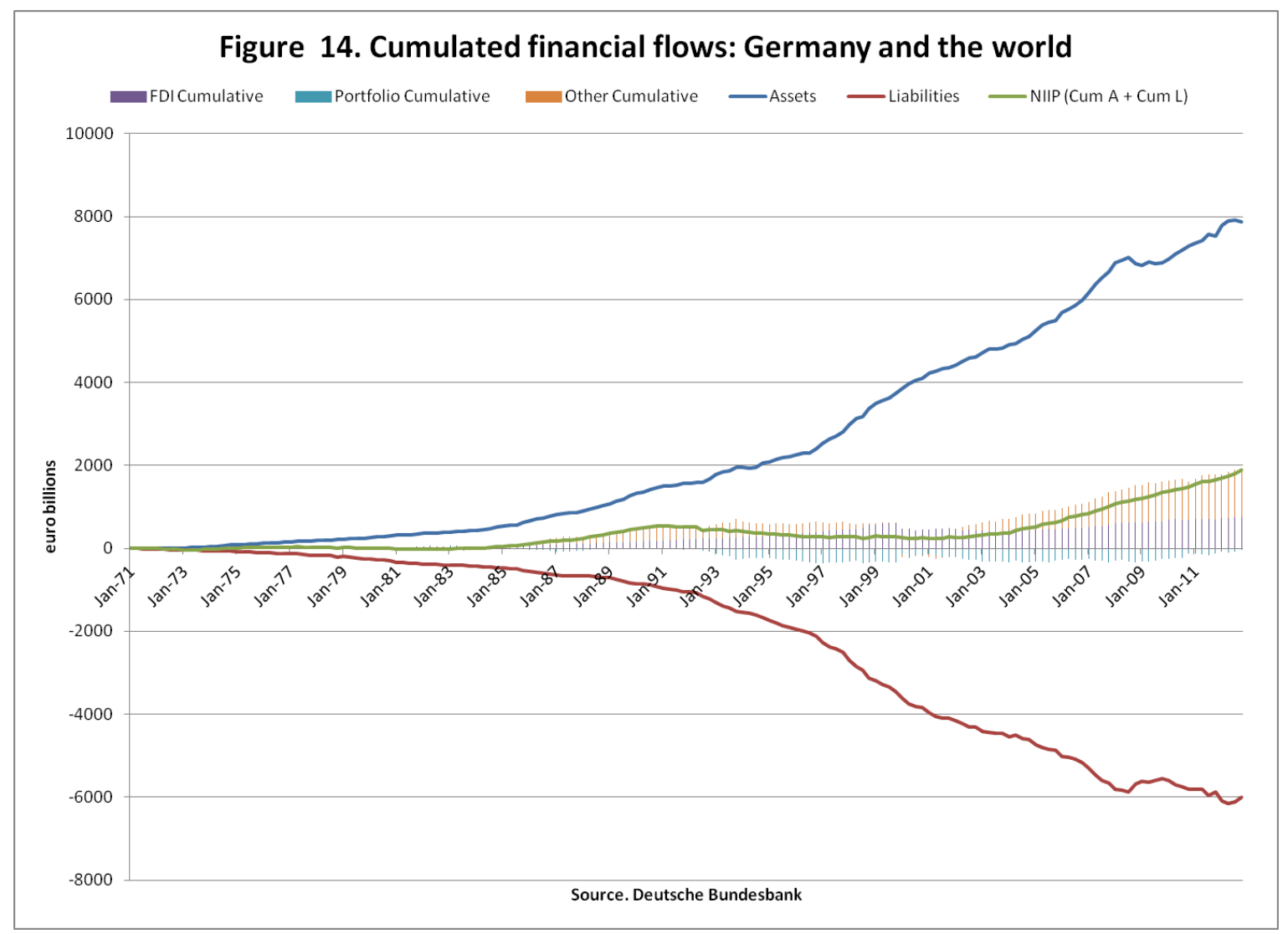

In summary, persistent, large current account surpluses in the 2000s have led to the buildup of a large international creditor position. The rise in foreign assets and liabilities was broadbased but especially strong in the other investment category. Within this category German banks were the driving force of expansion until crisis struck, when a sharp pull-back started that was mirrored in a corresponding rise of the Bundesbank's other investments. Compared to cumulated current account surpluses (or cumulated financial account deficits) there appears to be a large hole in Germany's NIIP reflecting negative valuation effects. No doubt the global financial crisis of 2008-09 and the ongoing euro crisis are the main culprits behind the aggregate national wealth impact. These observations refer to Germany's global IIP. The next two sections will attempt to glean more insights regarding Germany's external vulnerability from regionally disaggregated data starting with data on financial flows. 


\section{FINANCIAL FLOWS SUGGEST RISK CONCENTRATION IN EUROPE}

Cumulated financial flows suggest that Germany's cross-border flows - and resulting risk exposures - are chiefly concentrated in Europe (mainly EU and Switzerland) and, beyond Europe, in the United States. If anything, German cross-border financial flows seem to be even more regionally concentrated than German trade flows (Bundesbank 2008). For the European Union cumulated gross financial outflows exceed Germany's net creditor position of EUR 1.25 trillion by a factor of 4 (see Figure 15), with serious distortions in recorded flows as to the country composition to be explained momentarily. As to net positions other investment flows (mainly banks) are the dominant category here.

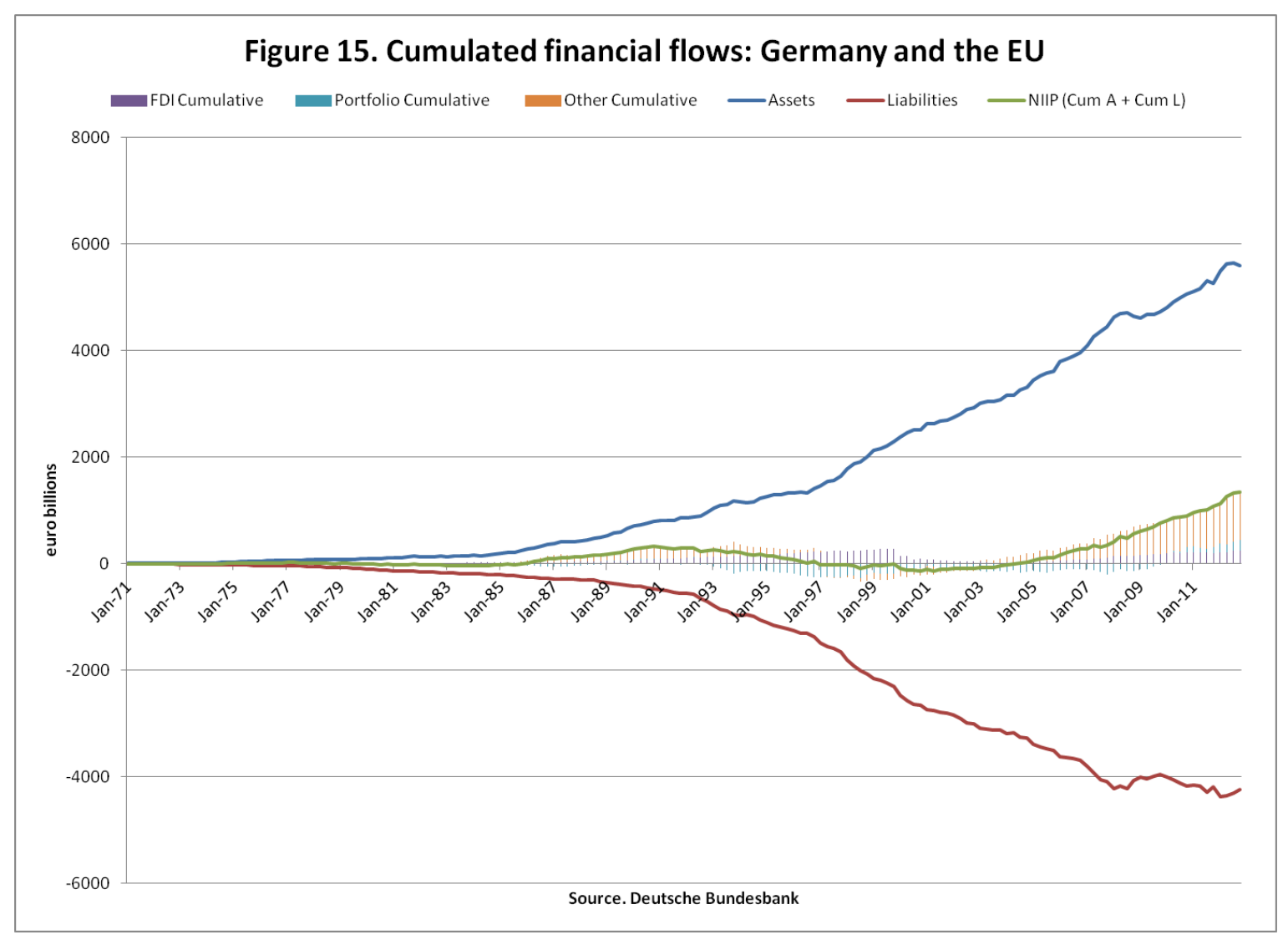

For the U.S. a large positive net FDI position stands out. Furthermore, while German banks traditionally had a negative net position vis-à-vis the U.S., this turned into a sizeable positive position by 2007 , which has however declined markedly since then whereas net portfolio investment exposure has seen a continued steady rise (see Figure 16). 


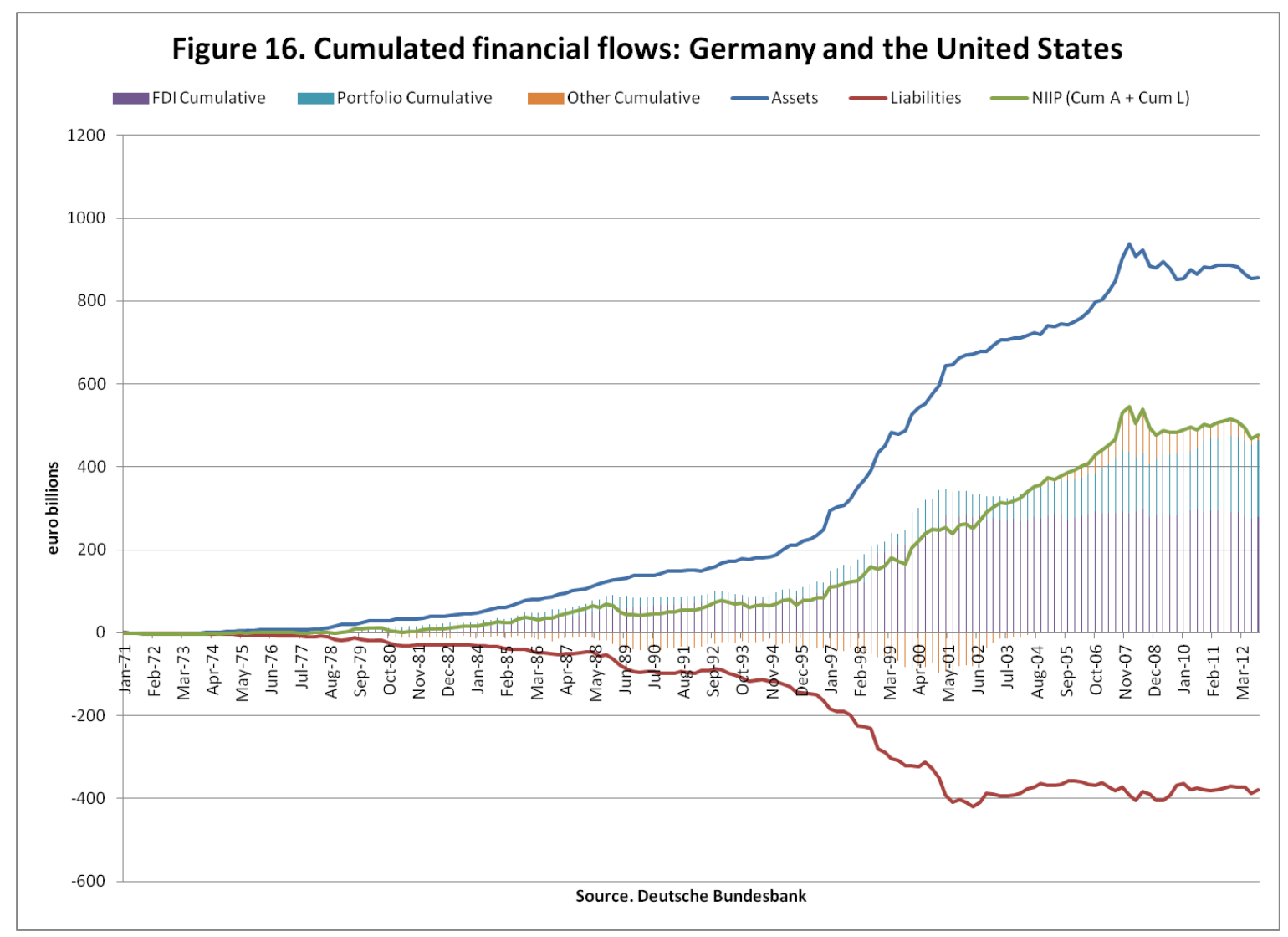

Unfortunately the disaggregated flow data offer only limited insights as to Germany's country-specific exposures within Europe. This is because financial flow statistics record immediate foreign counterparties in cross-border transactions rather than ultimate foreign investors/borrowers. Especially in the case of portfolio investment flows, discrepancies can be very large owing to brisk trading in secondary markets and the prominent presence of central securities depositories in Europe. In fact German financial flow data vis-à-vis Belgium, Luxembourg, and the U.K., in particular, are rendered completely useless by these circumstances. The former two since they host the central securities depositories Euroclear and Clearstream, respectively, which are handling the bulk of repayment flows. And the bilateral Anglo-German flow data is rendered useless by the fact that international trading in German Bunds is concentrated in London. While aggregate data for the European Union, including all three countries, is informative, aggregate data for Euroland, excluding the U.K., is not. As to individual countries other than these three, the results of the IMF's annual Coordinated Portfolio Investment Surveys (CPIS) suggest that distortions can be sizeable too. 
This is apparently the case for Greece and Ireland, for instance. While financial flow data shows an overall creditor position of just over EUR 60 billion (or roughly 2.5 percent of GDP) for Greece (see Figure 17) by the end of 2012, the CPIS for 2010 and 2011 suggests that the seemingly surging portfolio investment exposure in those years may actually have been significantly smaller. However, a possible explanation is also that large valuation losses were realized in this category at the time. A marked rise in other investment has occurred since 2010 reflecting the bilateral loans of the first Greek "bail-out".

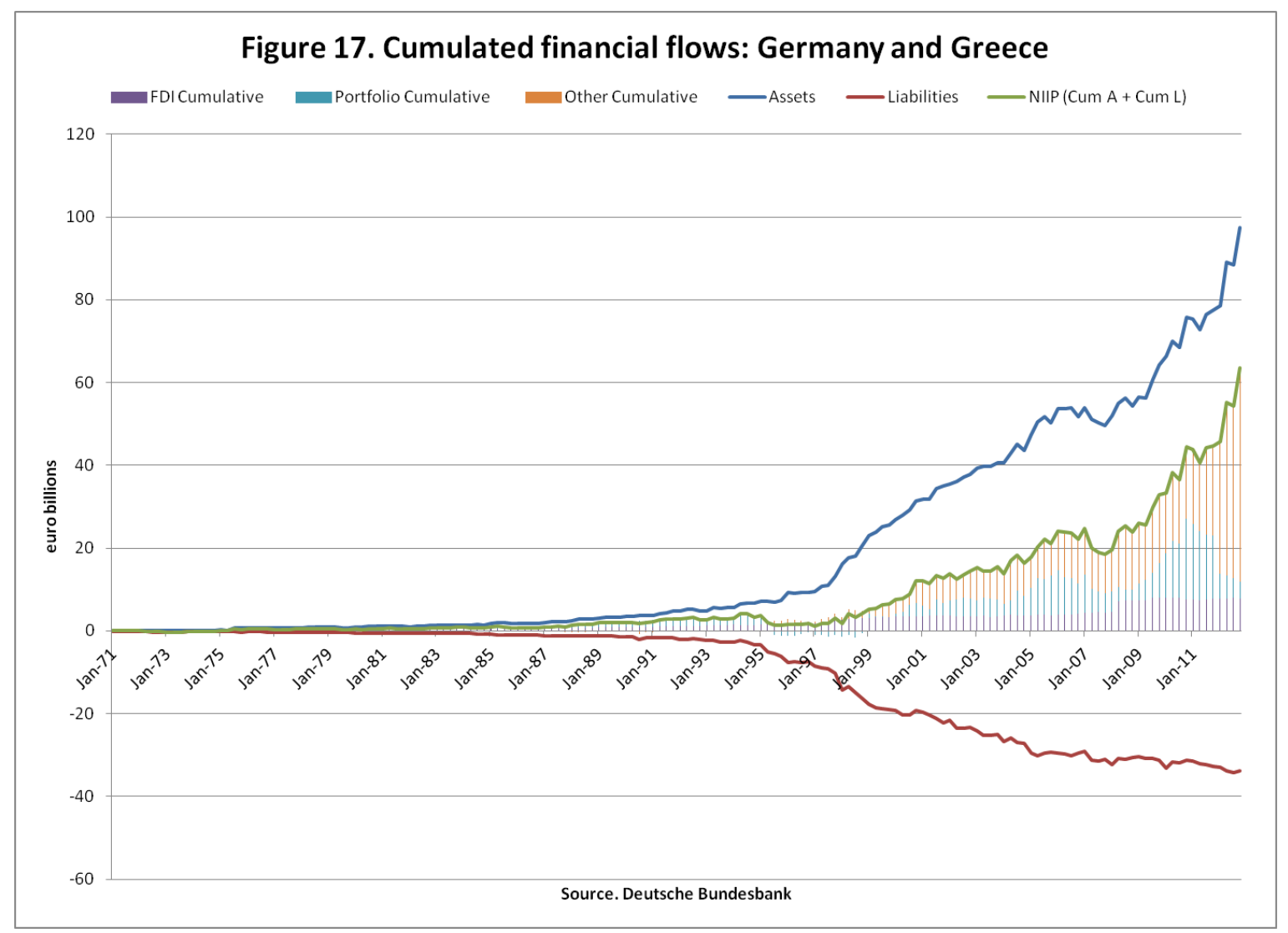

The picture for Ireland (see Figure 18) shows a creditor position concentrated in portfolio investment. A temporary surge occurred between the fall of 2008 and the fall of 2010 in the other investment category, reflecting intra-banking group support provided by a bank headquartered in Germany to an Irish affiliate (at the time of the infamous Irish bank guarantee scheme of late September 2008). With the other investment net position on the rise again since the spring of 2012, overall German exposure was around EUR 120 billion by the end of 2012 (or roughly 5 percent of GDP). However, CPIS data suggests that in 2010 and 2011 portfolio 
investment exposure was actually about three times larger than the cumulated financial flow estimate.

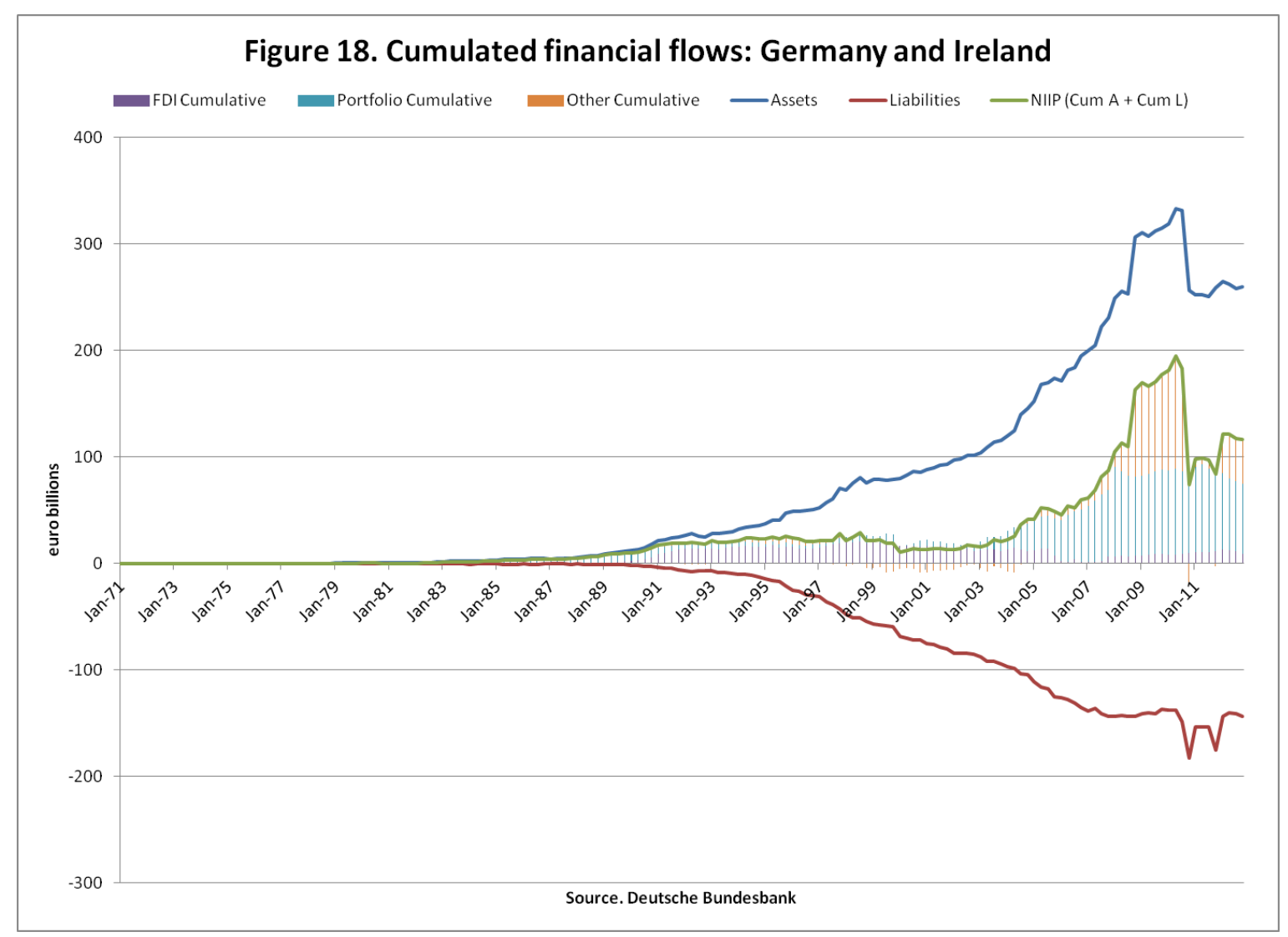

According to the CPIS of 2010 and 2011, distortions of the financial flow data appear to be more limited in the case of Italy, Spain, and Portugal. 


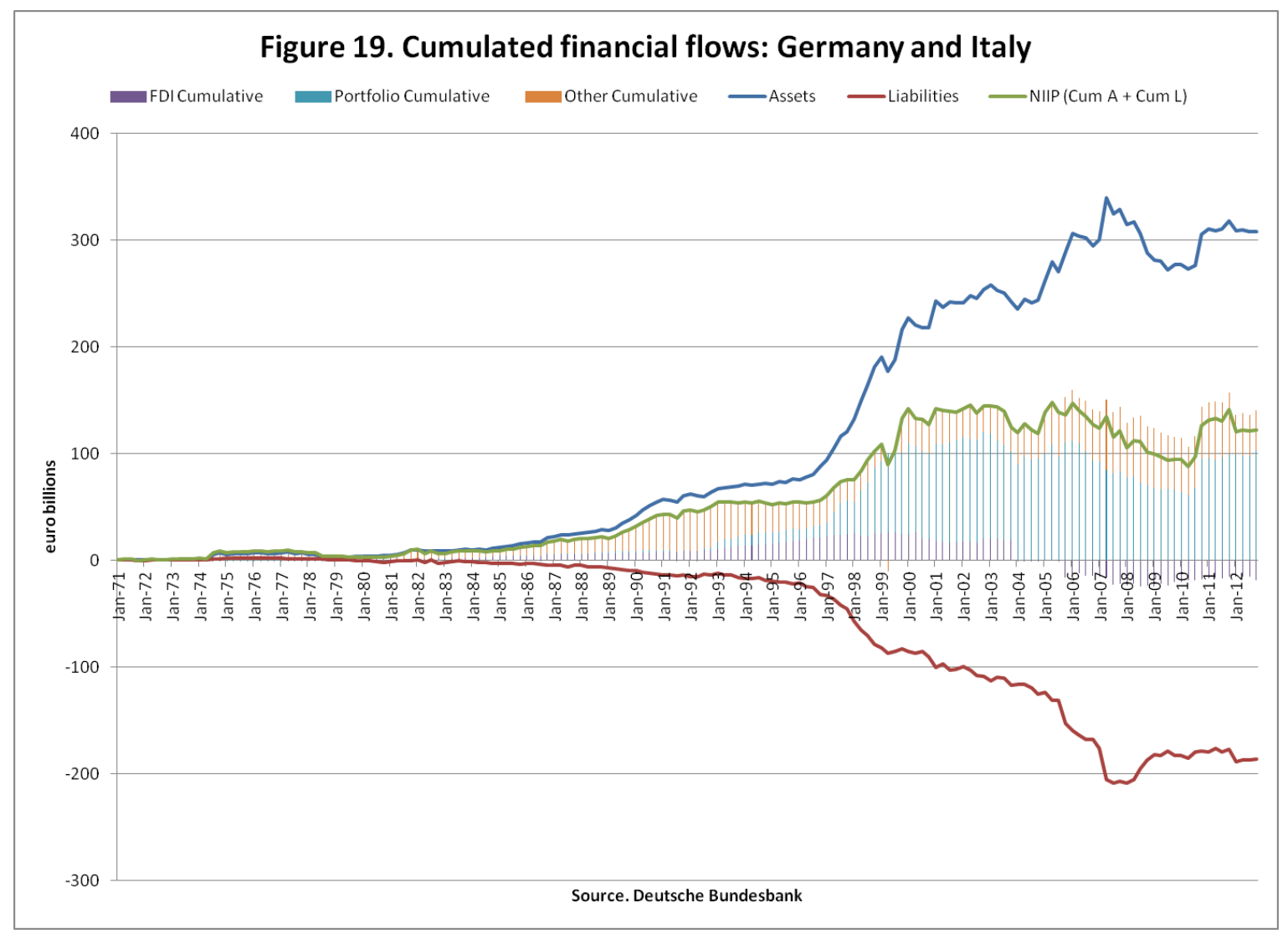

For Italy financial flow data shows a creditor position of around EUR 120 billion (roughly 5 percent of GDP) which is concentrated in portfolio investment. The net FDI balance shifted in Italy's favor in the mid-2000s (largely reflecting the acquisition of Germany's Hypo Vereinsbank by Italy's UniCredit Group). Since late 2010 net portfolio investment exposure has actually increased again (see Figure 19). 


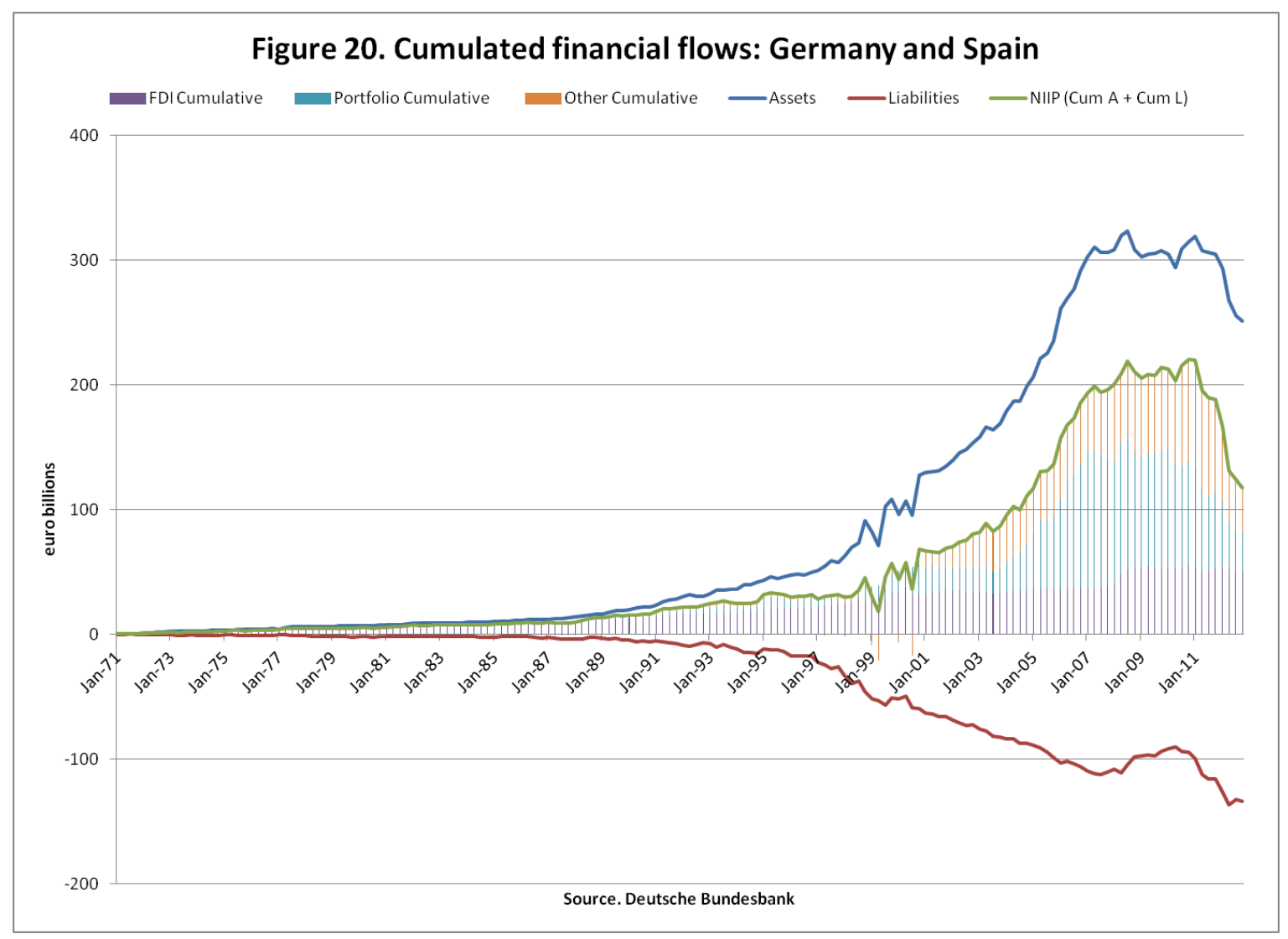

The picture for Spain shown in Figure 20 is very different. German exposure to Spain peaked at EUR 220 billion (roughly 8.5 percent of GDP) in early 2011 but has since declined markedly to EUR 120 billion by the end of 2012. While net exposures were quite balanced in all three categories at the peak, the retrenchment has been concentrated in portfolio and other investment flows. 


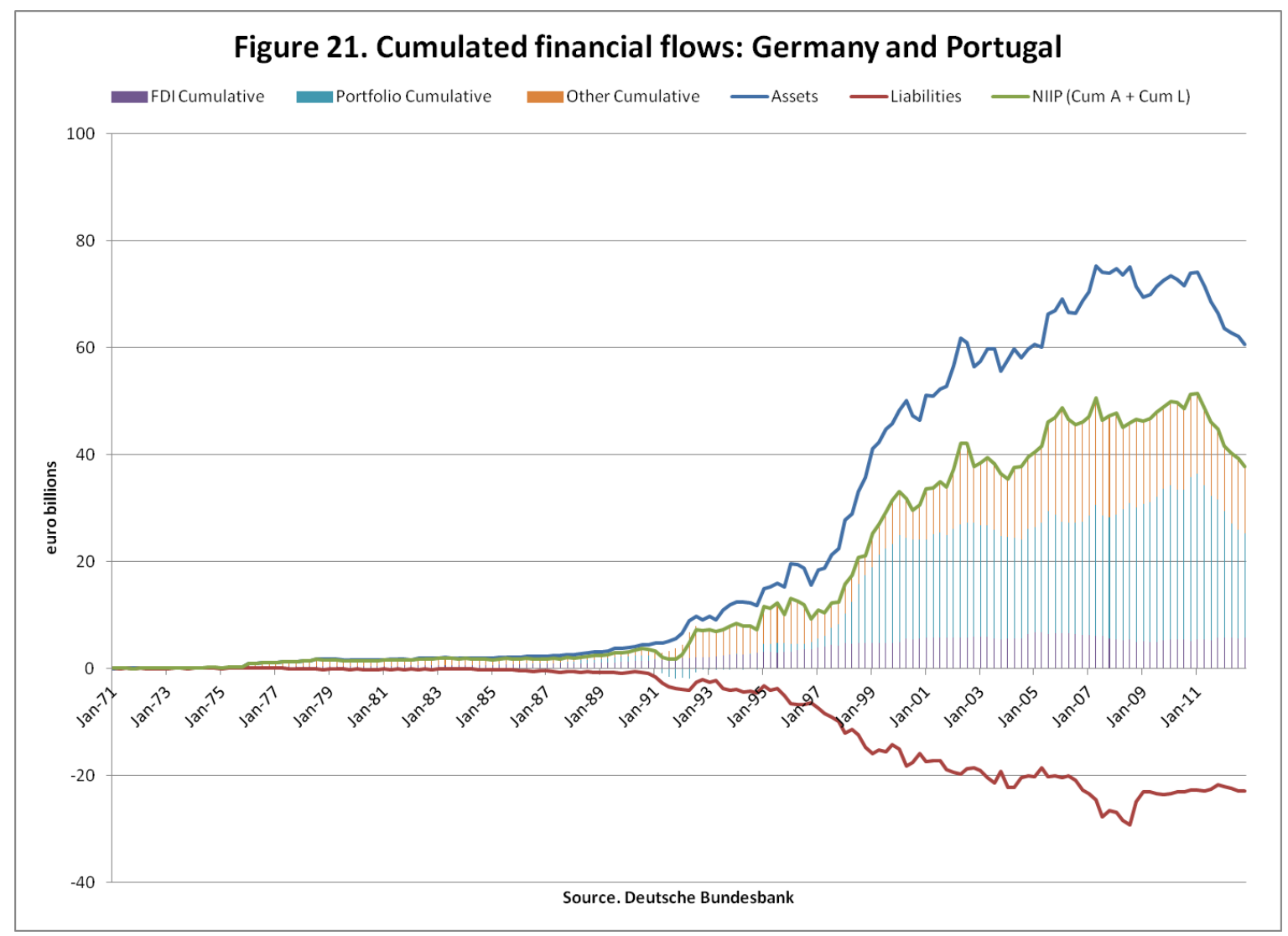

Similarly, as Figure 21 shows, German net exposure to Portugal peaked at EUR 50 billion (roughly 2 percent of GDP) in early 2011, concentrated in the portfolio investment category, but has since declined to below EUR 40 billion by the end of 2012 . 


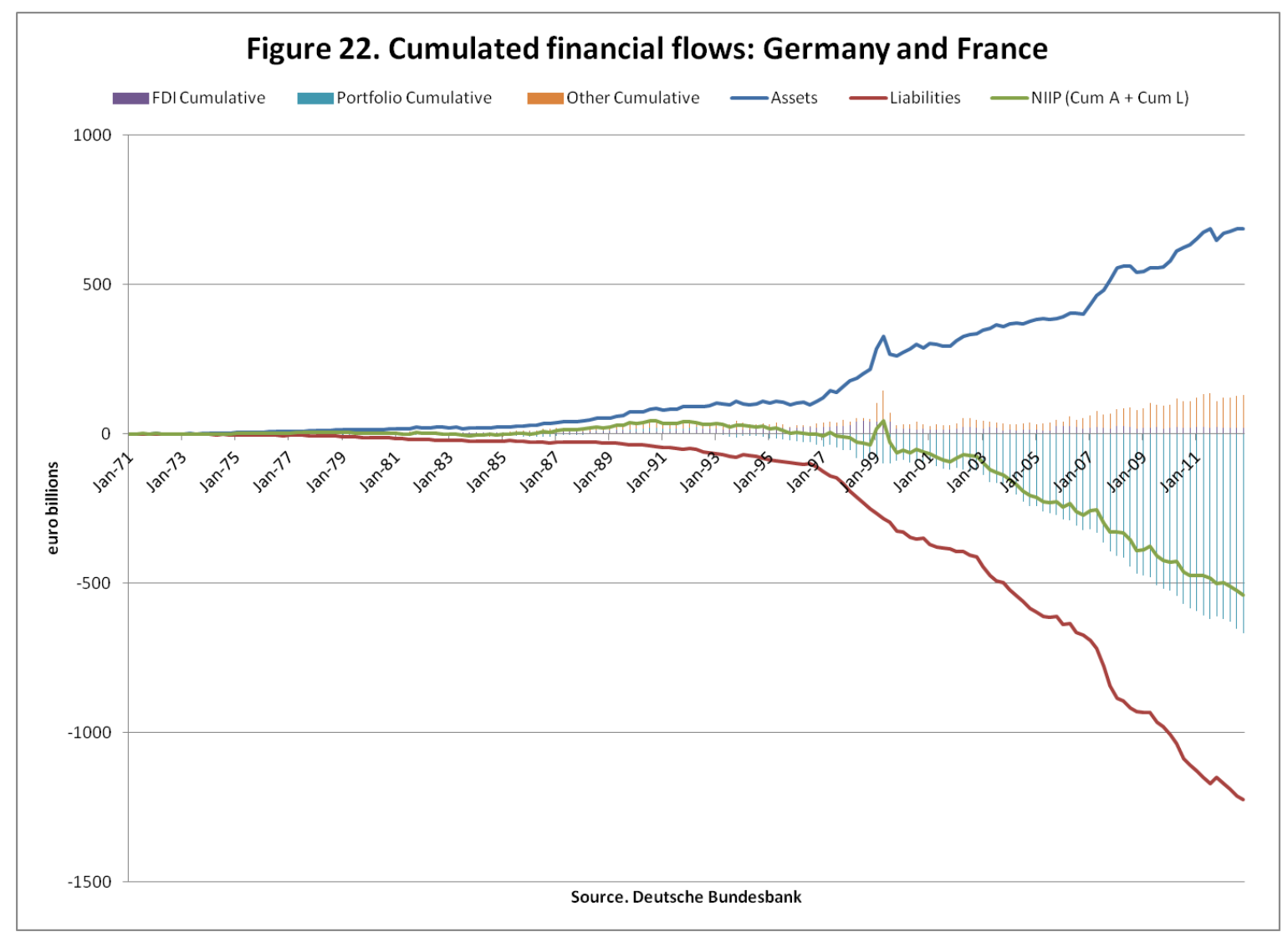

According to bilateral cumulated financial flows, Germany has built up a net debtor position vis-à-vis France under the euro that reached over EUR 500 billion by the end of 2012 and which is concentrated in portfolio investment (see Figure 22). However, the CPIS for 2010 and 2011 suggest that the actual portfolio investment position was less than half as large, in which case Germany's overall net debtor position vis-à-vis France may be around 8 percent of GDP.

To summarize, while financial flow data indicate that Germany's international financial exposures are concentrated in the European Union, important data distortions limit the degree of confidence with which exposures vis-à-vis individual countries may be estimated. Results are thus merely indicative in suggesting that by the end of 2012 Germany's net exposures to euro crisis countries may have been in the ballpark of EUR 500 billion or roughly 20 percent of GDP. On the other hand, Germany appears to have a net debtor position vis-à-vis France in the ballpark of EUR 200 billion. The next section complements the analysis of regional data on financial flows with an analysis of regional data on stocks. 


\section{SECTORAL BALANCE SHEETS CONFIRM EXPOSURES ARE CONCENTRATED IN EUROPE}

Apart from data on Germany's overall international investment position vis-à-vis the rest of the world, the Bundesbank also provides country-level data on sectoral balance sheets for German banks (Monetary Financial Institutions, MFIs) and non-bank enterprises. Starting with non-bank enterprises, the balance sheet data provided focuses on credit relationships but excludes equity capital. Overall, as Figure 23 shows, while both foreign assets and liabilities expanded quite strongly, the external net position of Germany's non-bank enterprises as far as credit relationships are concerned actually turned from a creditor into a debtor position (of just over 5 percent of GDP) under the euro.

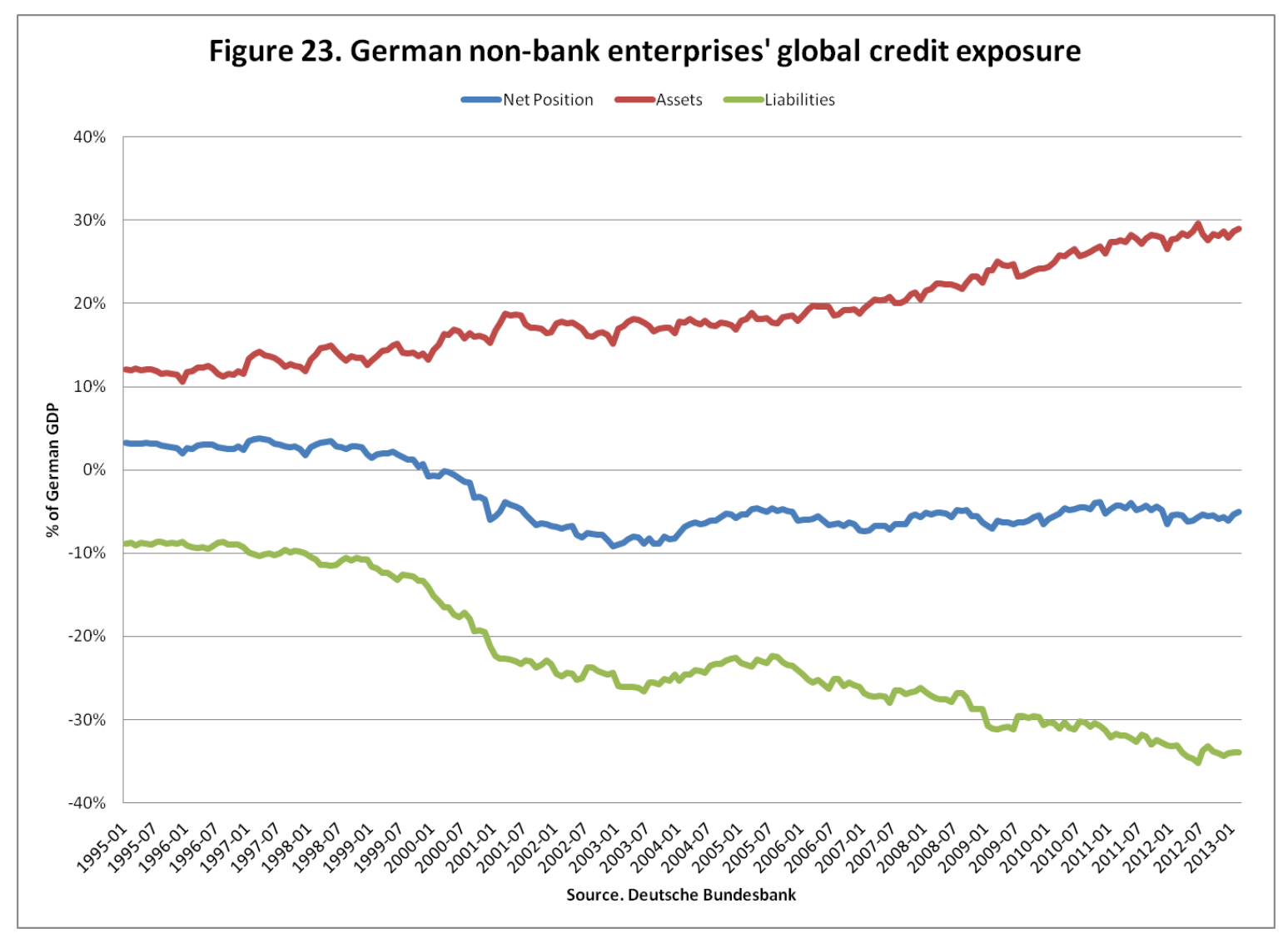

The non-bank enterprises' net debtor position is concentrated in Europe, specifically in the Netherlands and Luxembourg (see Figure 24). Tax advantages seem to be the key motivation. The Bundesbank (2009, p. 43) observes that "many [the number given there is: twelve] of the major multinational groups based in Germany established autonomous financing 
subsidiaries (also known as captive finance companies) in the 1980s and 1990s, primarily - for tax reasons - in the Netherlands." Similar reasons would seem to also apply in the case of Luxembourg (Houlder 2013). On the other hand, a net creditor position vis-à-vis France built up between 2007 and 2010, which partly reversed in 2011-12.

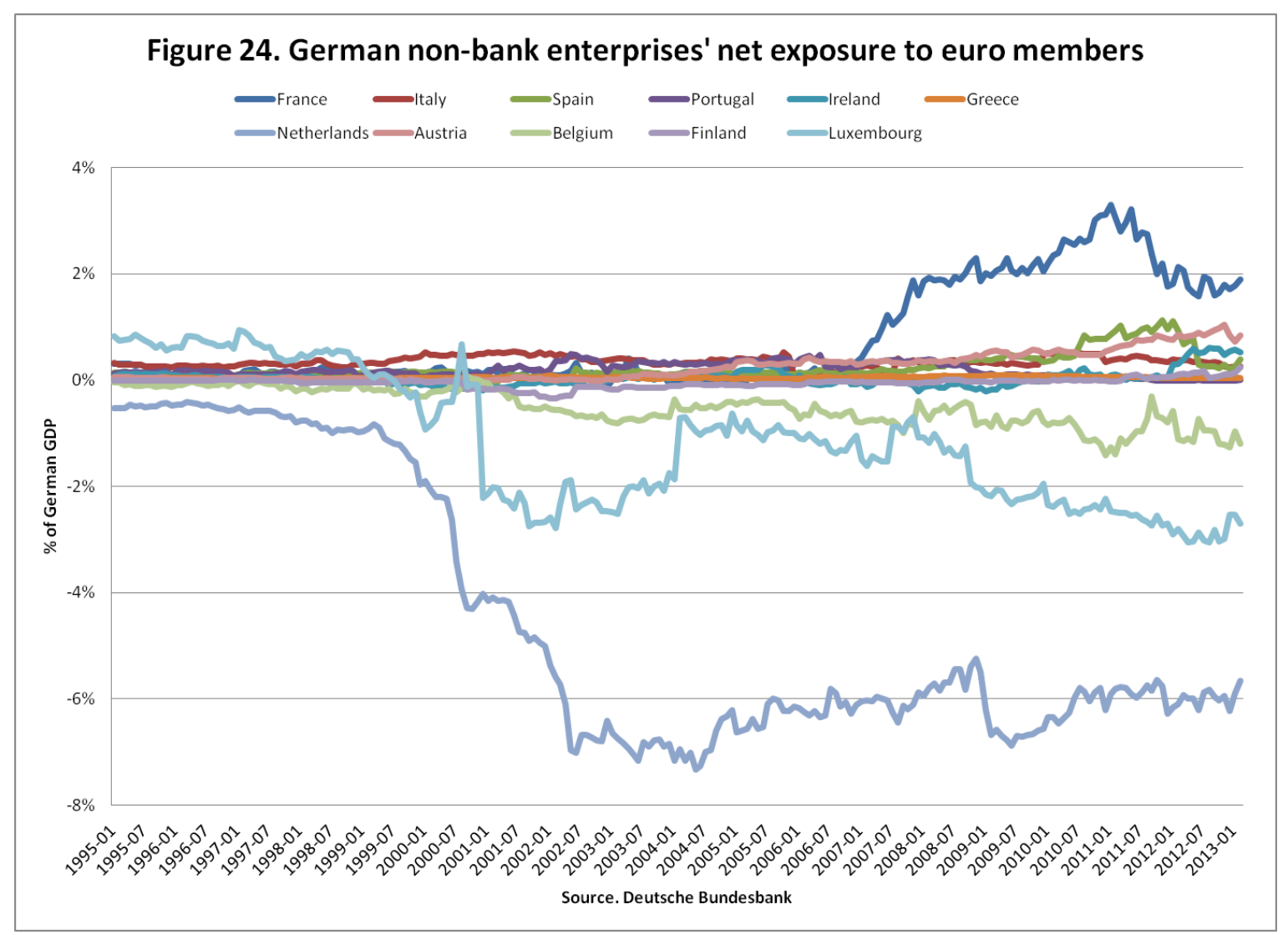

Turning now to MFIs and starting with the Bundesbank's non-consolidated data of banks located in Germany (including branches and subsidiaries of foreign banks), global assets and liabilities expanded strongly between the mid-1990s and the early 2000s. The "global slowdown" in the early 2000s then saw a mild reversal of this trend. While global liabilities then stabilized around 100 percent of GDP, global assets expanded again in the mid-2000s, peaking near 180 percent of GDP (see Figure 25). The bulk of MFIs' net exposure is concentrated in Euroland, with the U.S. and U.K. making up much of the rest. The ongoing retrenchment has been broad based from late 2008 until 2011. Since 2012 continued general shrinkage at a 
reduced speed in overall net exposure has been partly offset by a renewed rise in net exposures vis-à-vis the U.K. ${ }^{6}$

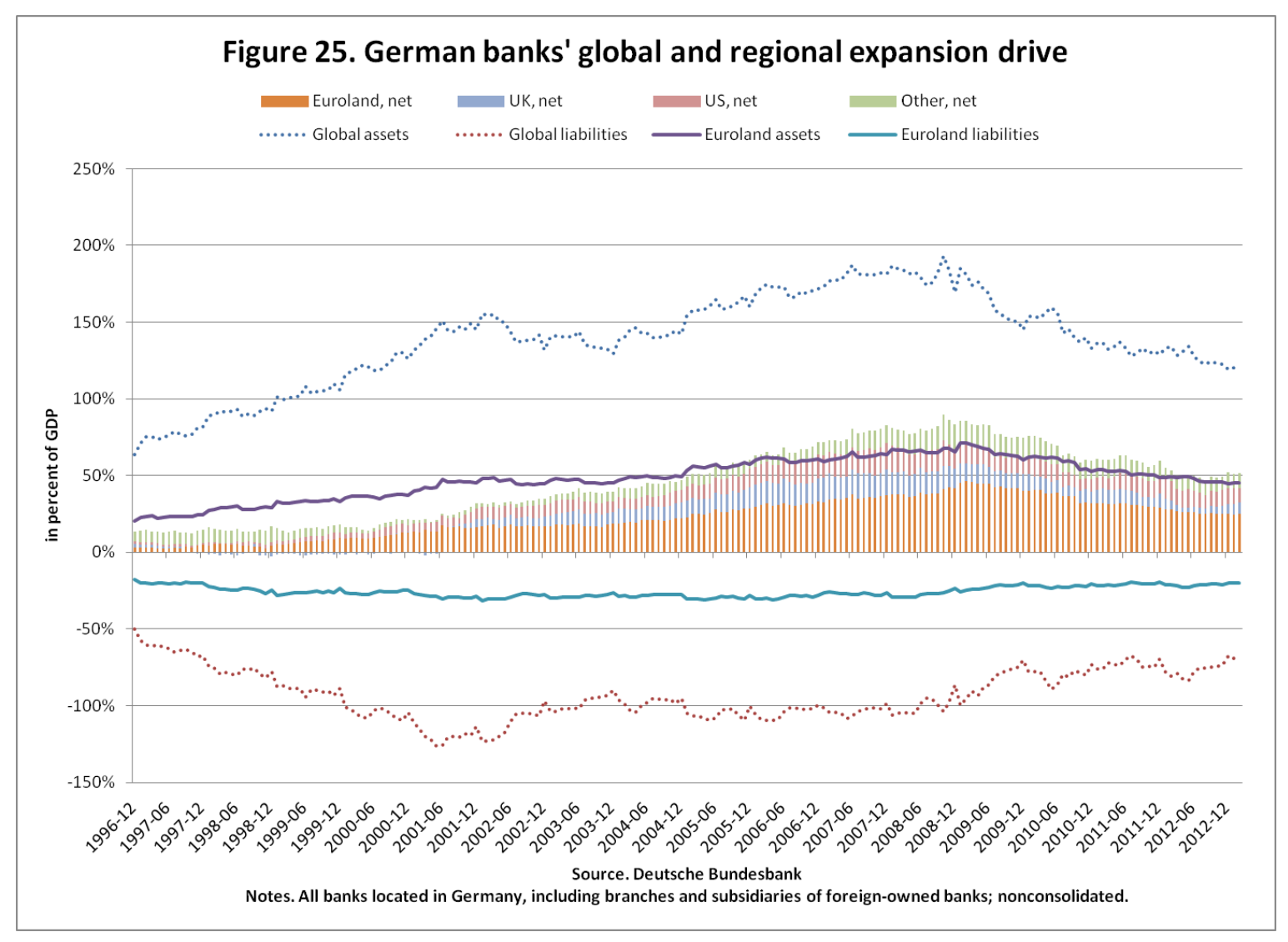

Within Euroland the relatively steady growth in net exposure vis-à-vis France stands in contrast to the boom-bust cycle visible in net exposures vis-à-vis Italy, Spain, Portugal, Ireland, and Greece, in particular. Negative net exposures vis-à-vis Luxembourg and the Netherlands turned into sizeable positive ones in the course of the 2000s (see Figure 26).

\footnotetext{
${ }^{6}$ On the broader picture of global banking retrenchment with its concentration among Euroland banks see Avdjiev et al. 2012, van Rixtel and Vause 2012a,b, and Vause et al. 2012, 2013.
} 


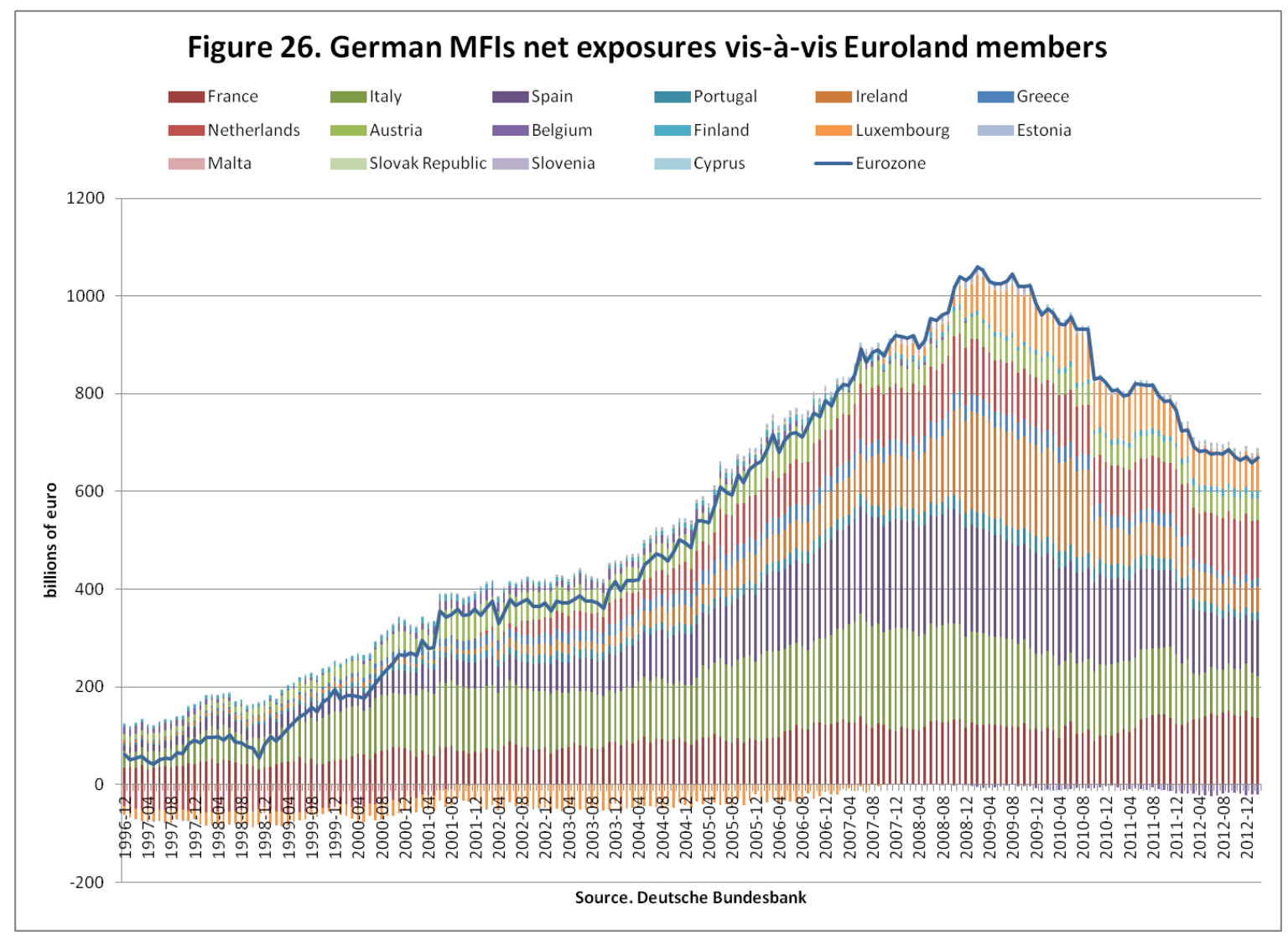

Figure 27 shows that net exposures vis-à-vis Italy, Spain, and Ireland each peaked between 8 and 10 percent of GDP around 2008 but have since declined to between 2 and 4 percent of GDP. As mentioned earlier, the temporary burst in net exposure to Ireland reflected support by a German bank holding to an Irish affiliate. 


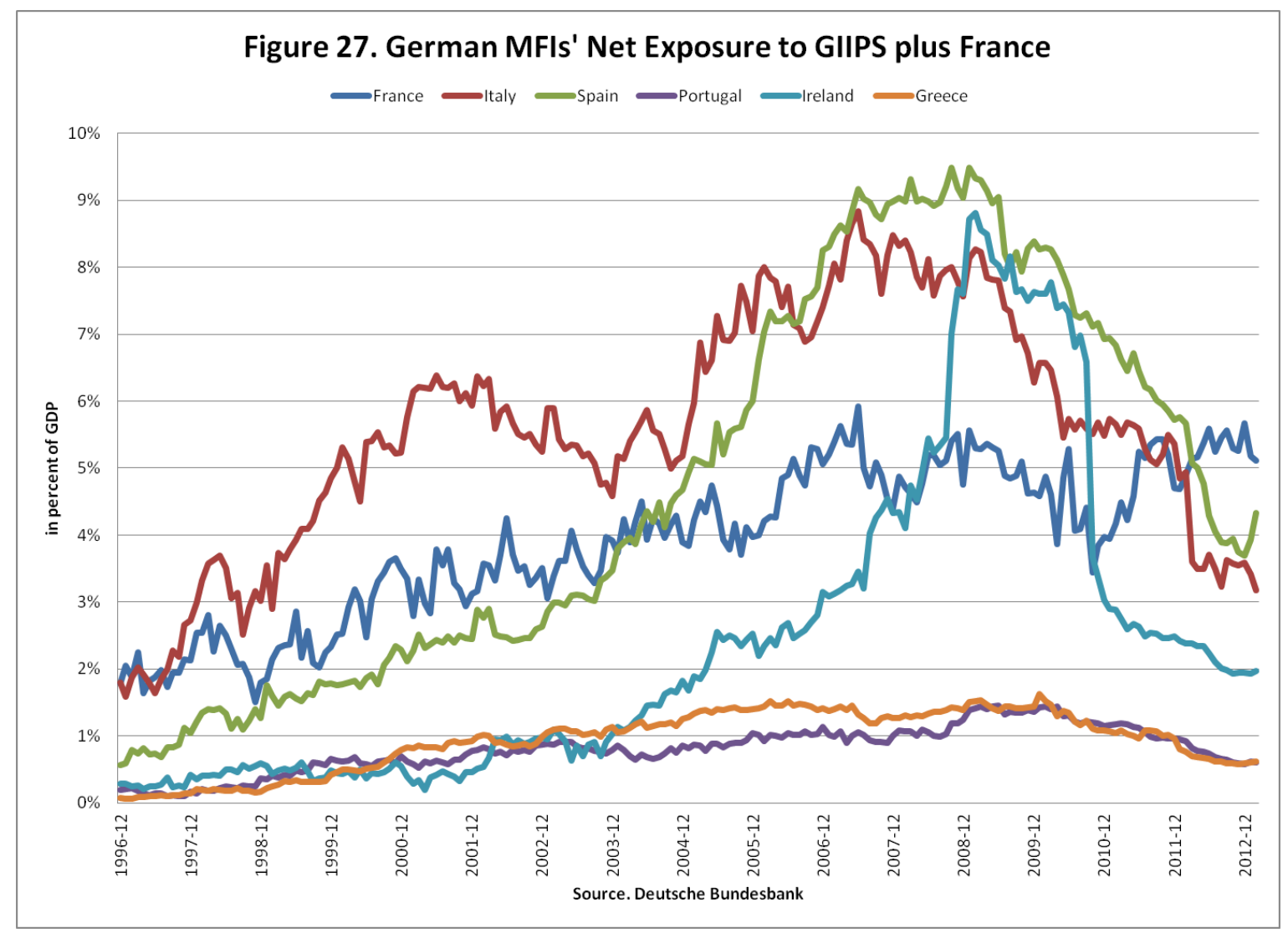

The Bundesbank's banking statistics referred to above follow the principles for locational banking statistics of the Bank for International Settlements (BIS), which provide insights into the nationality of ownership of reporting banks and the residency of reporting banks' counterparties. The above nonconsolidated data included inter-office positions. The BIS also publishes another set of statistics measuring banks' worldwide consolidated international claims both on an "immediate borrower" basis and on an "ultimate risk" basis. The latter statistics overcome the issue encountered above with financial flows, as they record ultimate borrowers rather than immediate counterparties, and also include hedges through credit default swap protection bought and parent or third-party guarantees. However, the BIS consolidated statistics only cover banks' foreign assets and only 11 Euroland members' banks are reporting to the BIS.

Figure 28 shows German banks' reported consolidated holdings of euro area assets on an ultimate risk basis. While a general withdrawal of exposure has occurred for most countries, the 
cycle of expansion and retrenchment has been sharpest in the cases of Ireland and Spain; down from 6 to 2.5 percent of GDP for Ireland and from 8.5 to 3.5 percent for Spain. ${ }^{7}$

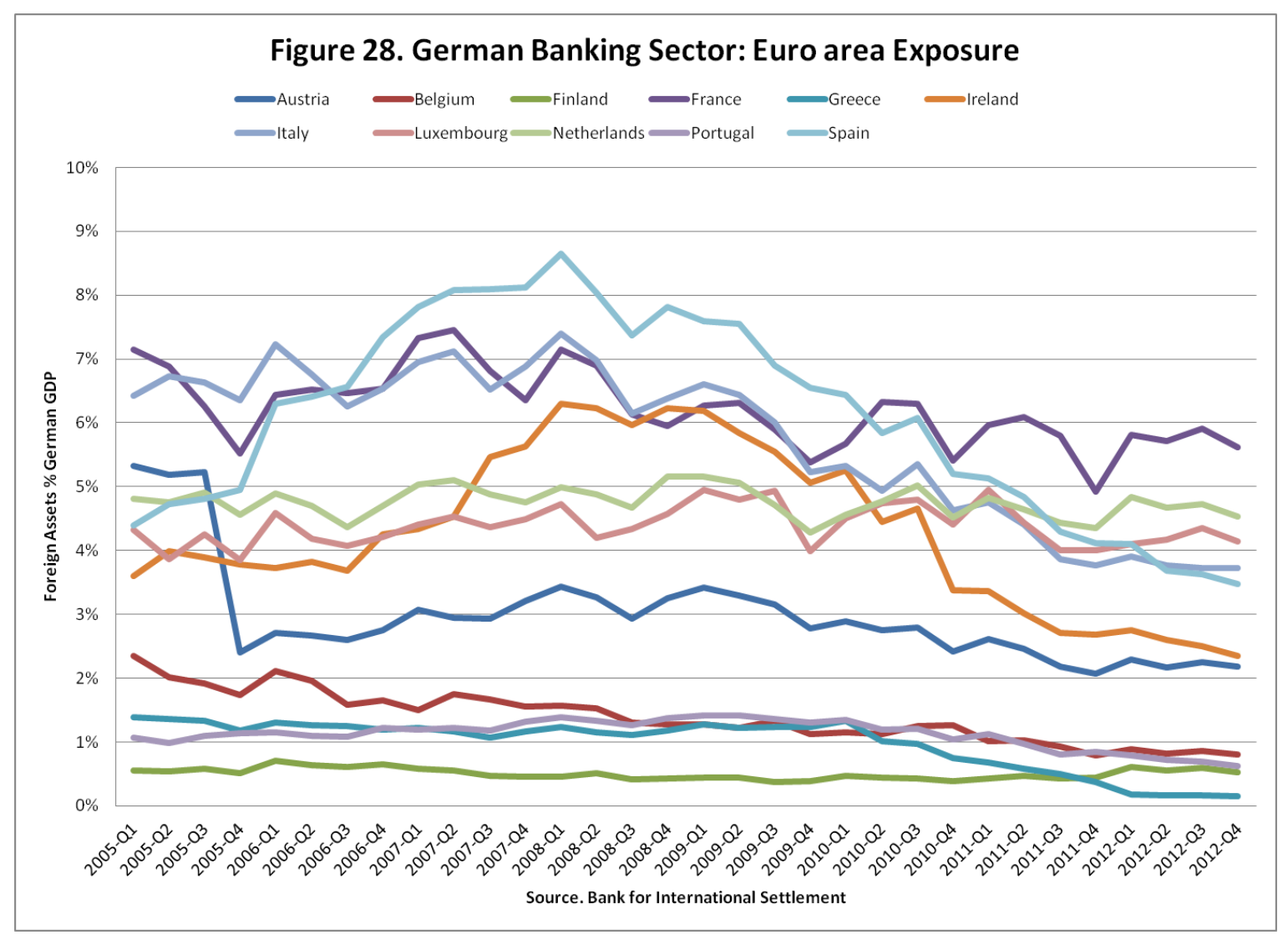

At least for reporting Euroland members it is also possible to calculate bilateral banking sector positions and net exposures on the basis of the BIS consolidated statistics. Figure 29 below shows German banks' ongoing retrenchment since 2008 vis-à-vis both key global players' and key euro member countries' banking systems. It appears that German net banking exposures vis-à-vis both Ireland's and Spain's banking systems have been reduced to 2 percent of GDP each. On the other hand, Germany's banking system has a negative net exposure vis-àvis Italy's since 2006 due to the aforementioned acquisition of Germany's Hypo Vereinsbank by Italy's UniCredit. Drastic reductions in net banking exposures can also be seen vis-à-vis the U.K. and the U.S. In both cases reduced net banking exposures not only owe to German banks’

\footnotetext{
${ }^{7}$ I suppose that the decline in German banks' holdings of Austrian assets reflects UniCredit's acquisition of Hypo Vereinsbank Group, which included ownership of Bank Austria.
} 
retrenchment but more recently also to expanded investment in German banks by U.S. and U.K. banks. ${ }^{8}$

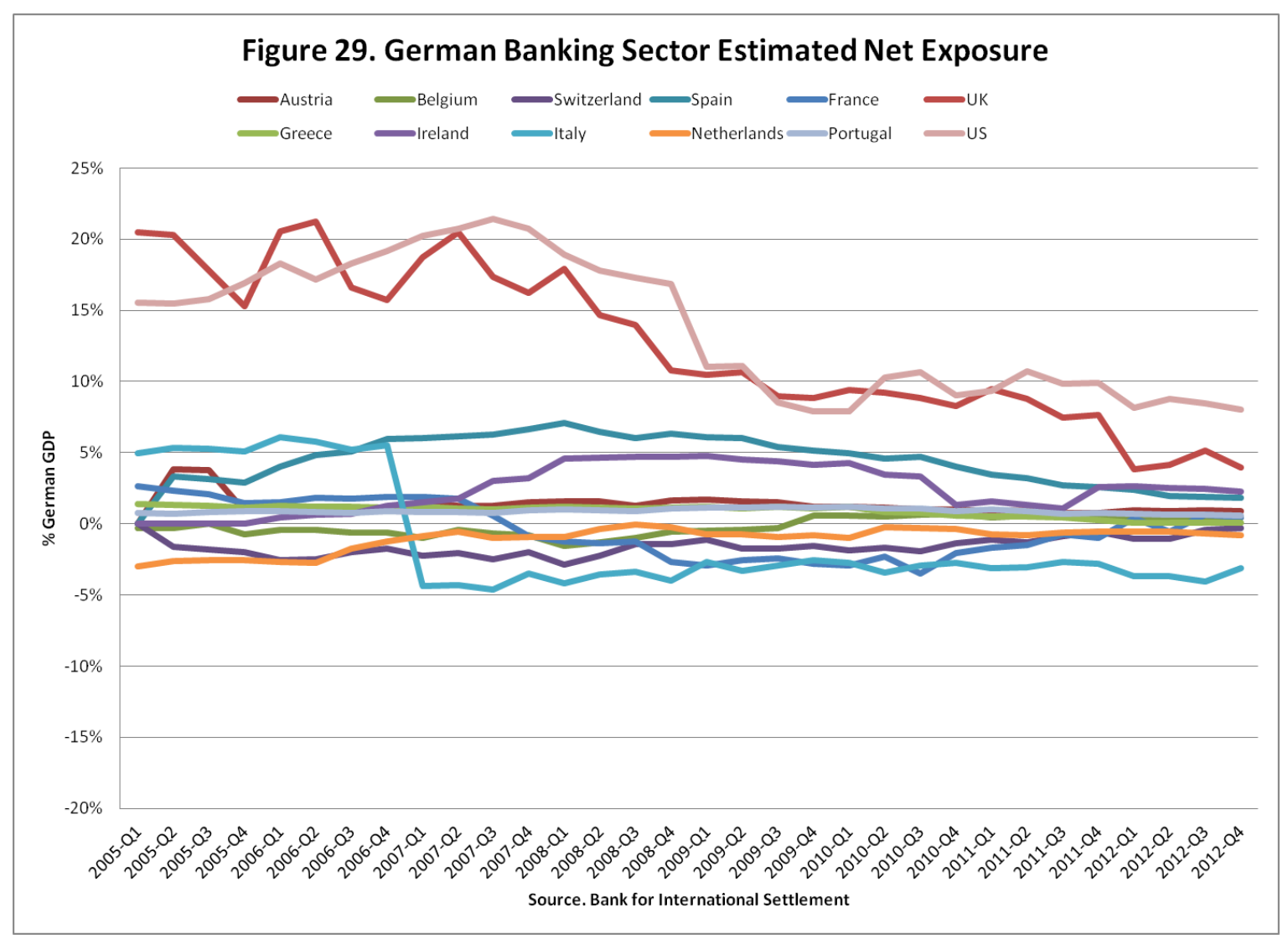

Figure 30 shows German banks' aggregate exposure to banks of euro crisis countries plus France, confirming that, overall, German banks' seem to have almost completely pulled out of this group of euro partner countries' banks. Any remaining net banking exposures vis-àvis Ireland, Spain, and Portugal are largely offset by the negative bilateral position vis-à-vis Italy, while the bilateral position vis-à-vis France is roughly balanced.

\footnotetext{
${ }^{8}$ As a contributor to the buildup of TARGET2 imbalances, Cecchetti et al. (2012, p. 9) report capital flow reversals within banking groups arising in an attempt to manage redenomination risk and involving "the Spanish affiliate to rely on the LTRO while the German one holds excess reserves in the Bundesbank. Shortening positions in the country with the presumed weak (proto-)currency and lengthening positions in the country with the presumed strong (proto-)currency is precisely how a bank manages (proto-)currency risk."
} 


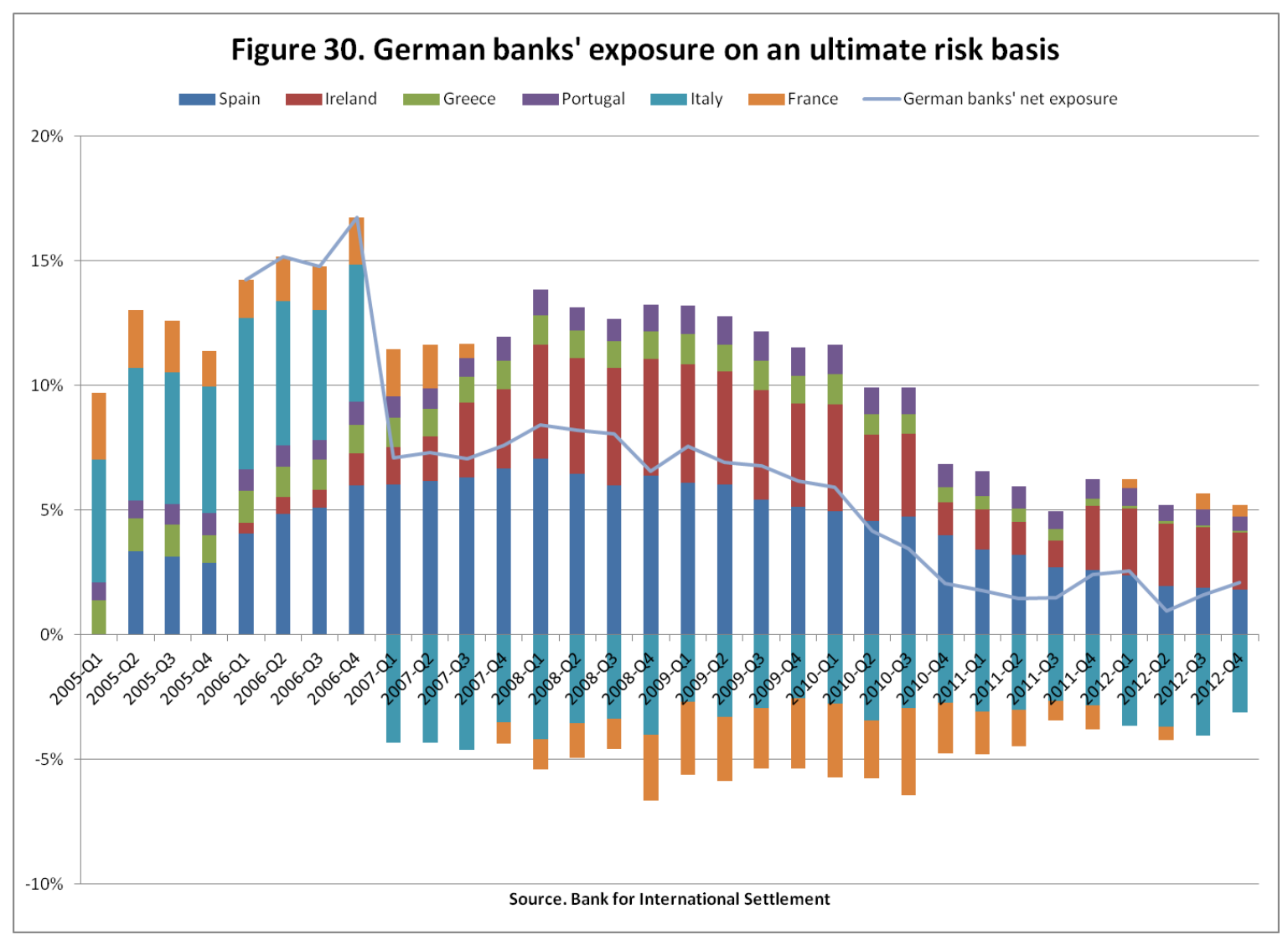

To summarize, German banks participated wholeheartedly in the exuberant global expansion drive that had also got into other European banking systems since the late 1990s. Sharp retrenchment followed and is still ongoing. Boom-bust cycles in German banks' engagements were strongest for Ireland and Spain, the two countries that experienced the greatest housing bubbles. Yet it appears that German banks have almost completely withdrawn their aggregate net exposure to banks of euro crisis countries plus France meanwhile. This is an interesting outcome not least because it could make a euro breakup of the form analyzed in the next section so much simpler. While there are surely remaining exposures, also to nonbanks and foreign governments, portfolio investment in euro partner public debt securities too have seen a sharp retrenchment. ${ }^{9}$

\section{SOURCES OF GERMANY'S VULNERABILITY}

\footnotetext{
${ }^{9}$ The European Banking Authorities' 2011 Stress Tests provide detailed insights as to the situation at the end of 2010 when banks' cross-border holdings were already well below their peak levels (see EBA 2011). Atkins and Fray (2013) also cover more recent trends.
} 
The above analysis informs our assessment of Germany's vulnerability to the ongoing euro crisis, featuring a potential breakup of the currency union as a worst-case scenario. In general, economic integration and interdependence imply two-way economic vulnerabilities even when trade is perfectly balanced at all time. With full financial liberalization as in Europe's Single Market, cross-border gross financial flows and asset holdings can be very large even when net international investment positions are zero. In case of sharp asset price movements, liquidity stresses, or defaults in any particular asset category, there is no reason to expect any arising losses to balance out across all assets and liabilities. Economic integration and two-way crossborder vulnerabilities are two sides of the same coin. After all, European integration was all about deliberately creating deep interdependencies as a means of making war impossible apart from any enhancements in economic efficiency (Schuman 1950).

The currency composition of Germany's foreign assets and liabilities is such that currency appreciation translates into valuation losses on Germany's part. Given the prominence of public debt (enjoying global safe-haven status) among Germany's foreign liabilities as opposed to mostly riskier investments on the asset side of Germany's international ledger, any rise in global liquidity preference (or risk aversion) also delivers valuation losses to Germany. Of course valuation losses may prove temporary and not become realized losses. The analysis in Section 4 above revealed that by the end of 2012 valuation losses since 2006 amounted to some 20-25 percent of German GDP. This estimate includes losses related to both the global financial crisis of 2008-09 as well as the ongoing euro crisis. Some of these valuation losses have been realized, including the Greek debt restructuring involving private sector involvement of April 2012 , for instance). But a good part of valuation losses, especially arising from the ongoing euro crisis, is still in the form of "paper losses" at this point that may be partly or wholly recovered under more favorable conditions (even if not by the original purchaser who may have passed on the asset at a depressed price).

Apart from any realized market price related haircuts, the euro crisis has actually meant a mixed bag for Germany in terms of valuation losses. For instance, by depressing the external value of the euro the crisis has had a favorable impact on Germany's international balance sheet. At the same time, by lifting the prices of Bunds, the crisis has had a seemingly negative impact on Germany; while of course conveniently depressing the financing costs on that part of Germany's public debt that is being rolled over (and similarly for private sector financing costs 
too). As German equities have greatly outperformed their European peers in recent years, this factor too has boosted German valuation losses.

While all these channels - featuring portfolio composition effects - would also be at play in the case of a zero NIIP, Germany's vulnerability was magnified by the fact that, resulting from persistent current account surpluses, the country has actually run up a very large net creditor position. Making matters worse still, Germany's net creditor position is highly concentrated in Europe, specifically Euroland; while Germany's key international liability, Bunds, have a more global presence. Chen et al. (2012) refer to peculiar European financing patterns in the 2000s that saw core Europe finance peripheral Europe's ballooning current account deficits while the rest of the world actually accumulated claims on core European governments. Whatever may have motivated individual German lenders and investors at the time, the German authorities in charge have somehow missed the inevitable truth that running perpetual export surpluses vis-à-vis Germany's euro partners - made possible by liberal German (re-)financing of exuberant over-spending on their part - has left Germany as a nation extremely exposed to anything that would worsen its euro debtors' credit rating, and the situation in its euro debtor partner countries more generally. As Germany's NIIP surged to 40 percent of GDP, those of its euro partners deteriorated accordingly, in the cases of Greece, Portugal and Spain approaching negative 100 percent of GDP; which is extraordinarily high by international standards (Reinhard and Rogoff 2011). Alas, bankrupting your partners, who are both your buyers and your debtors, is just not such a smart strategy. In pre-euro times eventual deutschmark appreciation served to (partly or temporarily) rebalance competitiveness positions and debt burdens. ${ }^{10}$ The euro has shut that door supposedly permanently - without however also shutting the door for imbalances to build up.

Ironically, it appears that Germany's single biggest risk sits on the Bundesbank's balance sheet. More than half of Germany's net creditor position consists of the Bundesbank's infamous TARGET2 balances at the ECB. In Germany these TARGET2 claims against the $\mathrm{ECB} /$ Eurosystem have given rise to some remarkable excitement. Some commentators depict them as reflecting flaws in the design of the Eurosystem (Sinn and Wollmershäuser 2012).

\footnotetext{
${ }^{10}$ We noted above that valuation losses are not a new experience for Germany but a recurrent pattern in the postWWII era. Of course Germany’s low inflation record and uncovered interest parity would suggest so.
} 
Others seem to interpret them as evidence of the heroic Bundesbank being subjected to plunder by Germany's profligate euro partners (Burda 2012).

While TARGET2 imbalances are indeed a symptom of the ongoing euro crisis, the Bundesbank's credit balances are above all else evidence of a multi-billion favor paid by the ECB to German banks by allowing them to pull out of their interbank lending to bank counterparties in euro crisis countries largely without loss (Bibow 2012b, Soros 2012). As the analysis in Sections 3-5 above revealed, the German banking system went on a splurge in the 2000, both across the Atlantic and around the globe and especially in Euroland, but has since drastically retrenched their regional and global engagements. In the process large losses were realized on U.S. mortgage-related instruments. And sizeable losses were surely also realized on portfolio investments in euro crisis countries. But in the case of banks' other investments featuring the all-important interbank loans, which prior to the crisis were largely unsecured, the ECB's emergency liquidity support spared German banks massive losses that inevitably would have resulted without the ECB's liquidity backstopping of the euro area banking system(s) (see also Bibow 2012a).

The Bundesbank's TARGET2 balances are not new exposures but simply the reincarnation of old exposures previously built up on, largely, German banks' balance sheets. In particular, the refusal on the part of German banks, among others, to roll over interbank loans made to euro crisis countries in exuberant times would have bankrupted the problem banks in euro crisis countries more or less immediately. Importantly, it is not just that German banks' credit counterparties would have failed on that occasion, with corresponding write-downs on interbank loans. Correspondingly greater fire sales across other asset classes and markets would have hit German banks, among others, indirectly too. It was of course for the latter - systemic risk of contagion that the ECB stepped in to support banking systems faced by wholesale market bank runs, rather than to do any particular German bank any favor. Preserving the euro simply compelled the ECB to do what it did. But the result nonetheless was that the ECB did German banks a great big favor indeed. And since it is safe to assume that the German government would have bailed out any failing German banks hit by their exposure to euro crisis countries, the ECB ultimately did German taxpayers a great favor too - which does not stop German tabloids and other ignorant commentators from accusing the ECB of the opposite. 
That favor may turn out to be no more than a temporary boon though, especially in case of euro breakup. For the Bundesbank's TARGET2 balances at the ECB are subject to loss, with losses being shared among euro member states according to their respective central banks' ECB capital shares. Currently Germany's capital share is 27 percent. One could therefore also say that ECB emergency liquidity support for euro area banking systems has successfully mutualized three quarters of potential German bank losses. At least for the time being, that is. For in case of a euro breakup the loss sharing would surely be up to re-negotiation and dependent on the precise form that any breakup would take. In any case, as the whole purpose of a euro breakup would be that of achieving debt relief for euro crisis countries, apart from restoring intra-regional competitiveness positions, the Bundesbank is facing potential losses up to its total TARGET2 balances. These peaked at EUR 720 billion or 27 percent of GDP in October/November 2012 but have since declined to 23 percent of GDP by April 2013. Depending on the form of euro breakup actual losses could arise from either currency valuation effects or write-downs. Alternatively, TARGET2 balances could result in permanent implicit transfers through foregone central bank profits (seigniorage) and/or greater public borrowing costs.

The media typically envision euro breakup scenarios in which either one particular or the whole group of euro crisis countries would leave the euro. The focus then is on Germany's (or the so-called core's) direct exposures vis-à-vis the exiting country or countries. In my view, if a euro breakup turns out to be unavoidable, the "best" way to break up the euro would be to split the currency union at its Franco-German axis. Regarding competitiveness positions France is in the same boat as Italy, Spain, Portugal, and Greece. Broadly speaking, the resulting "euro south" would be internally balanced. And the common exchange rate would allow smooth external rebalancing for the euro south group. France has high exposures vis-à-vis its southern euro partners. And France has a TARGET2 debtor position that could partly off-set its bilateral creditor position vis-à-vis Germany. So this "best" (worst-case) euro breakup scenario would essentially have Germany exit what would become the euro-south, with other partners facing the choice of either remaining on the euro (south) led by France or aligning themselves with Germany's "new deutschmark". 11

\footnotetext{
${ }^{11}$ Austria and the Netherlands are the most likely countries to go back on the (new) deutschmark. For others, especially Belgium, this would be a tough call.
} 
In this euro breakup scenario written-down TARGET2 balances would leave a sizeable hole in the Bundesbank's balance sheet and the German finance ministry would need to recapitalize the Bundesbank (i.e. hand over public debt instruments to its central bank). Since interest paid on these debts adds to the Bundesbank's profit to be remitted to the finance ministry, euro breakup would seem to be a wash and, according to Whelan (2012), come at no cost to Germany as "recapitalization would have no impact on either the net asset position of the German state or its budget deficit". Unfortunately this argument misses two rather important points. ${ }^{12}$ One issue is that whatever the effects of the intra-public-sector debt bookings may be, there would still be a corresponding hole in Germany's international investment position. Internally it may be true that what started out as private loans by German banks, then temporarily migrated onto the Bundesbank's balance sheet, became eventually "replaced" by German public debts. But externally these original loans by German banks represented a foreign asset that either required the debtor country to run current account surpluses to retire the debt or to earn and pay a perpetual income stream in Germany's favor. Surely losing a foreign asset represents a loss to Germany; just as turning the foreign asset into a perpetuity that pays no interest involves an implicit transfer.

The second issue is that unless the new deutschmark generates a phenomenal demand both at home and abroad - for the Bundesbank's over-sized monetary base in case of monetizing the TARGET2 hole, the Bundesbank will have to sell interest-bearing instruments to mop up excess market liquidity; at least as soon as it diagnoses that its monetary policy stance requires a positive interest rate. And given that the re-born Bundesbank will be keen to underscore its much-cherished hawkish reputation this date would arrive sooner rather than later. ${ }^{13}$ For this purpose the Bundesbank could either issue interest-bearing term deposits or sell the public debt securities received from the finance ministry for purposes of its recapitalization, for instance. One way or another there would be an impact on both Germany's net public debt and public budget, either through higher interest payments or foregone seigniorage income;

\footnotetext{
${ }^{12}$ To his credit it must be said that Whelan (2012) thoroughly debunks the usual German TARGET2 fairytales. De Grauwe and Ji 2012 too partly misconstrue the issue of potential losses to Germany in case of euro breakup while rightly emphasizing the capital/deposit flight issue.

${ }^{13}$ One may assume here that re-emergence of a global demand for (new) deutschmark notes would restore Germany's pre-euro share in global seigniorage income. The introduction of the euro involved some redistribution in Germany's disfavor, as criticized vehemently by Sinn and Feist 1997 at the time (see also Sinn 2007); ignoring the important point that the global attractiveness of the old deutschmark was bolstered by the behavior of Germany's EMS partners.
} 
even if the public debt effectively used to properly bail out German banks once the ECB's provisional liquidity bail-out has failed to prevent euro breakup is permanently stored away on the Bundesbank's balance sheet. ${ }^{14}$

There is no way around it: Ultimately the Bundesbank's TARGET2 balances are German fiscal liabilities. In the case of a euro breakup with debt relief for euro crisis countries, German public debt would see a corresponding jump, as exchange rate realignments can no longer deliver on debt burden sharing under the euro. But euro breakup would re-open that blocked avenue. The actual loss from the Bundesbank's TARGET2 balances may turn out to be smaller than the potential loss of currently over 20 percent of German GDP but is likely to be sizeable in any case. As a partial offset in the case of a German exit from the euro (south), any other ECB losses (on sovereign bonds purchased under the Securities Markets Program, for instance) would most likely stay with the euro (south) members.

Another part of Germany's exposure consists of the various "bailout packages" and joint rescue facilities established since the crisis. It started with the first Greek bailout package of May 2010 undertaken through bilateral loans (EUR 110 billion). Next, there were the "Troika" bailout packages for Ireland (EUR 85 billion), Portugal (EUR 78 billion), and again Greece (additional EUR 130 billion), this time facilitated through the European Financial Stability Facility (EFSF) and European Financial Stability Mechanism (EFSM). The former has a lending capacity up to EUR 440 billion, the latter up to EUR 60 billion; topped up by up to EUR 250 billion in lending capacity by the IMF. Finally, established as a permanent Euroland firewall and rescue mechanism in 2012, the European Stability Mechanism (ESM) has a total lending capacity of EUR 500 billion. EUR 100 billion of the ESM's lending capacity were earmarked as a support package for recapitalization of the Spanish banking system. The bailout package for Cyprus (EUR 10 billion) of March 2013 was facilitated through the ESM. Germany's share in the joint and several guarantee commitments backing the EFSF and the ESM is 27 percent. The EFSM is guaranteed by the European Commission with the budget of the European Union serving as collateral. Again, potential losses depend on the timing and form of any euro breakup scenario, in particular. Assessing Germany's exposure to risks related to these bailout packages

\footnotetext{
${ }^{14}$ Supposedly whatever instruments issued by the central bank as a non-monetary base instrument would be accounted for as public debt. Using a "floor system" in implementing policy and paying interest on (pseudo) reserves might look after the impact on net public debt but not avoid the budget impact. See Berentsen et al. 2013.
} 
and joint rescue facilities is also complicated by the fact that the paid-in capital behind these joint rescue vehicles is relatively small and that the ultimate liabilities due to joint and several guaranteed borrowing may become subject to re-negotiation. In my view, Germany's potential losses under this heading are in the ballpark of 5 percent of GDP.

Finally, there is a considerable remaining private sector exposure the exact magnitude and location of which remains unclear. Thanks to ECB accommodation German banks may have largely shifted their former exposure to euro crisis countries, especially their interbank exposures (other investment), onto the Bundesbank's balance sheet. But Germany's nonbank private sector, specifically the private household sector, has net foreign assets of over 40 percent of GDP, concentrated in Europe, a sizeable share of which will be negatively affected by a euro breakup. Investment is concentrated in portfolio debt and much of it intermediated by nonbank financial intermediaries (pension funds, mutual funds, and insurance companies, in particular). If German valuation losses of around 20 percent of GDP, as quantified, above consist of largely realized losses stemming from the global financial crisis plus as yet largely unrealized losses related to the euro crisis, the potential for further losses on this account would still be very sizeable. In my view, Germany's potential losses under this heading are in the ballpark of 10-15 percent of GDP.

The bottom line is that there is simply no way around the fact that Germany would be squarely on the hook in case of a euro breakup. Overall, it seems, German losses on foreign assets could wipe out a good chunk of the country's 40 percent of GDP net international investment position. There would be a corresponding jump in Germany's public debt ratio as the counterpart to TARGET2 losses or bailouts of German insurance companies, for instance. Perhaps a greater part of Germany's overall exposure might migrate onto the Bundesbank's balance sheet before the actual breakup happens through continued re-fragmentation of European financial markets, which would actually simplify matters enormously.

Probably the most practicable form of euro breakup would be for governments to clear and offset the (euro area) foreign assets and liabilities of their respective nationals. Each government would make creditors among its nationals whole while assuming the counterparty role to nationals with foreign debts. (Re-)Negotiation among governments would focus on net foreign debt positions. Debt relief would arise through partly or wholly nullifying net foreign 
debts. One might remember here the generous London Debt Agreement of 1953, which allowed (West) Germany to recover under highly favorable conditions (while the victorious U.K., for instance, remained saddled with very high war debts). Neither negotiation of a debt settlement nor the actual euro break-up are likely to happen smoothly though. ${ }^{15}$

Apart from the debt relief issue, euro breakup could also swiftly restore intra-regional competitiveness positions. Just as West Germany recovered and thrived under favorable exchange rate conditions in the 1950s, today's euro crisis countries would welcome the much needed boost to their competitiveness to arrive in a non-deflationary fashion. Instead, Germany would see a deflationary rebalancing of its regional competitiveness position.

The size of the new deutschmark's appreciation is thus the other big factor in any breakup scenario, shaping both the magnitude of currency valuation losses (or write-offs) as well as the abrupt loss in German competitiveness. Of course, as a matter of pure logic, in order to accomplish the required regional rebalancing, Germany has to accept a sustained loss in relative competitiveness vis-à-vis its euro partners anyway. In case of Germany's main euro (south) partners: France, Italy, and Spain, this roughly requires a 20-25 percent shift in competitiveness positions. One issue is whether this rebalancing is undertaken in a symmetric (i.e. broadly inflation neutral) or asymmetric (i.e. deflationary) fashion. Another issue is whether the rebalancing happens gradually or abruptly.

Euro breakup would bring about abrupt rebalancing by force. Germany would see a sharp worsening in competitiveness overnight. The new deutschmark would probably even overshoot, dealing a massive deflationary blow to the German economy. In addition to the potential losses on German foreign assets identified above implying a corresponding jump in German public debt (the stock issue), a large budget deficit (the flow issue) due to a deep recession and surging unemployment would magnify the Germany's fiscal plight. A large budget deficit in a shrinking economy makes for explosive public finances - the very situation

\footnotetext{
${ }^{15}$ Evidence on historical currency breakup suggests that breakups can be achieved quickly and without lasting macroeconomic volatility (Rose 2007). Bootle (2012) provides a fairly comprehensive "practical guide" on the matter, Athanassiou (2009) discusses legal issues relevant for euro breakup.
} 
that euro crisis countries are in today. All in all, it is not hard to see Germany's public debt ratio surging beyond 120 percent of GDP in case of a euro breakup. ${ }^{16}$

Put differently, Germany has a lot to gain from preventing this outcome. Resolving the euro crisis and putting the currency union on a sounder footing for sustained area-wide growth would even mean recovering valuation losses for Germany. Has Germany pursued its own best interest in managing and resolving the euro crisis then?

\section{EUROLAND CRISIS MANAGEMENT, DEBT LEGACIES, AND DEBT MUTUALIZATION}

Bibow (2012b) diagnosed that resolving the euro crisis features three key challenges: first, internal rebalancing to restore intra-area equilibrium; second, arranging burden sharing to deal with debt legacies; and third, establishing a viable euro policy regime by fixing the flaws in the Maastricht regime. Add robust GDP growth as a vital precondition since addressing these challenges without growth would make the task so much more demanding if not impossible.

As to the precondition, it is quite remarkable that euro crisis management has not missed any chance to suffocate domestic demand. Following the initial "Keynes moment" of 2009 that featured a sizeable fiscal stimulus on Germany's part, Euroland quickly changed course in 2010 to fully embrace unconditional austerity under German leadership. The G-20 Toronto Summit of June 2010 marked the policy U-turn unfolding in Europe at that time, and also the start of postcrisis divergence in trans-Atlantic macro policy stance (Bibow 2009, UNCTAD 2010). The argument that the markets forced austerity upon Europe - as vividly experienced in the escalating Greek crisis - is missing the point. The markets did not force austerity upon Germany. Instead, Germany, enjoying super-low interest rates, chose to wholeheartedly embrace austerity out of conviction while welcoming and even enticing market discipline as punishment of its euro partners for their supposed past sins.

In 2012, Germany completed its zealously pursued mission of balancing its public budget, following austerity measures of roughly 3 percent of GDP in 2011-12. While growing

\footnotetext{
${ }^{16}$ Deo et al. 2011 provided an early analysis highlighting Germany's vulnerability. See also Cliffe et al. 2012 and Schumacher and Dourmaguet 2013.
} 
strongly in 2010-11 on the back of the global recovery, unsurprisingly, the German economy came to an abrupt halt in 2012. In the final quarter of 2012, the German economy shrank at an annual rate of over 2 percent, further deepening the recession that has savaged Euroland since mid-2011.

But the consequences of German-style "growth-friendly" fiscal consolidation are felt around the globe. With domestic demand shrinking at an annual rate of 2 percent, Euroland is freeloading on, and undermining, the global recovery (see Figure 31).

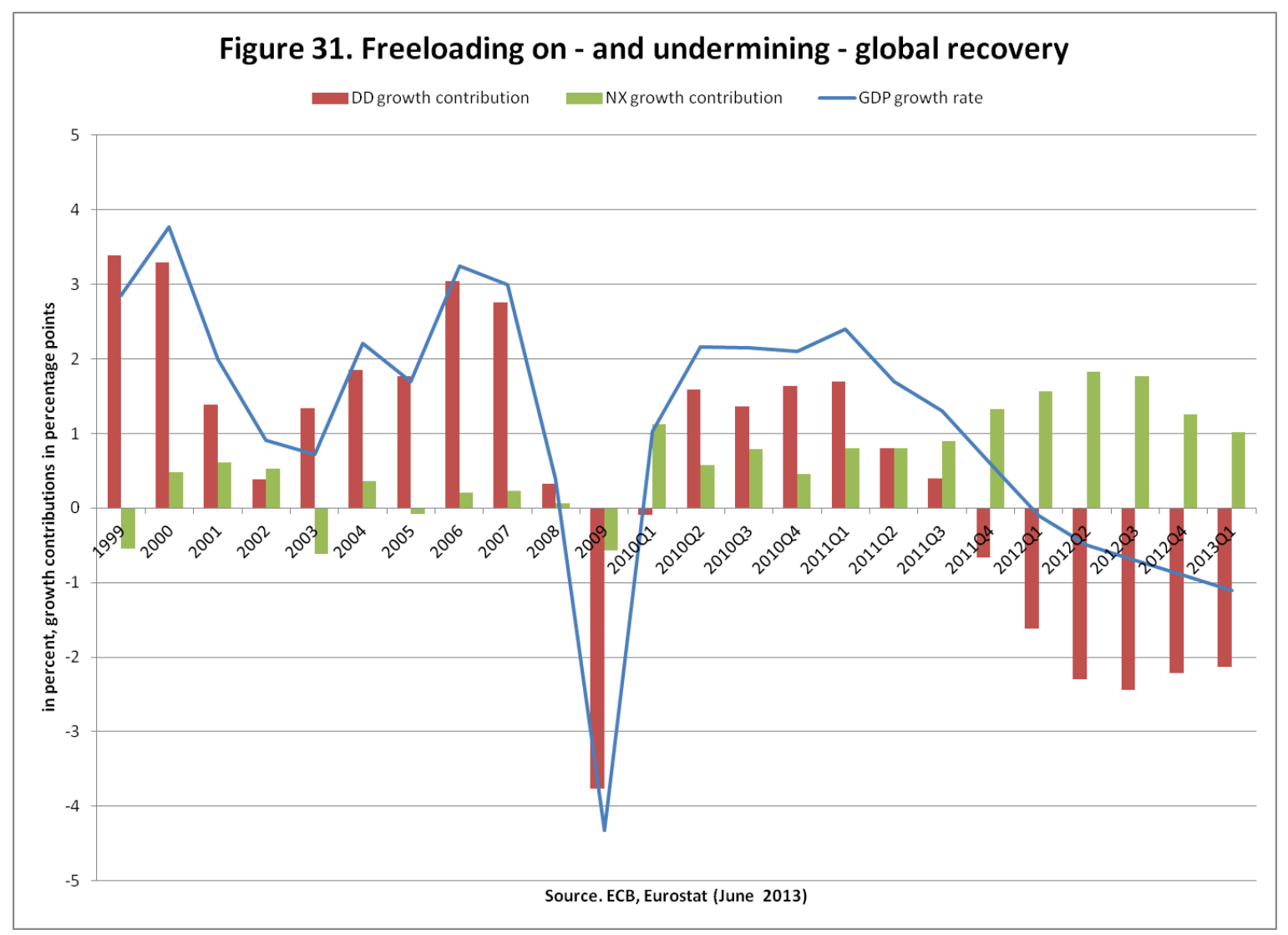

Symmetric rebalancing would have required an inflation-neutral macro policy stance for the union as a whole (i.e. macro policies in surplus countries that offset austerity in crisis countries together with temporarily elevated wage-price inflation in surplus countries). Symmetry was not tolerable to Germany though. ${ }^{17}$ Instead, competitive austerity simultaneously pursued continent-wide has been an important driver of the ongoing asymmetric rebalancing

\footnotetext{
${ }^{17}$ Intra-area rebalancing logically entails Germany losing intra-area competitiveness but Bundesbank president Weidmann (2012) represented the German view that this would require adjustment on the part of deficit countries only, asking "how can Europe succeed in this world if we willingly give up our hard-won competitiveness?"
} 
process that is pushing euro crisis countries into debt deflation. While Germany managed to balance its public budget on the back of bloated external surpluses, the euro crisis countries, laboring to restore their competitiveness through a deflationary process of "internal devaluation", are facing explosive public finances. Ignoring the smaller member countries here, Spain is the most acute case among the larger ones. Spain's nominal GDP of 2013 is 4 percent below its 2008 peak level. Spain's budget deficit, which was around 10 percent of GDP in the last four years, is forecast to decline towards 6 percent of GDP in 2013. Meanwhile Spain's public debt ratio has shot up from 40 to 100 percent of GDP in 2013, with deflation magnifying debt problems in Spain's private sector too, implying rising needs to de-leverage private balance sheets and recapitalize the banking system. A scenario that has Spain balances its public budget and stabilizes public debt below 120 percent of GDP is conceivable, but would require rather large growth stimuli from exports.

The situation appears to be more favorable in Italy since nominal GDP in 2013 is only 1 percent below its 2008 peak level and the public budget deficit only 3 percent of GDP. Alas, Italy's public debt ratio is already 130 percent of GDP and the economy continues shrinking. Finally, there is the critical case of Germany's euro-axis partner, France. So far at least nominal GDP growth has stayed in positive territory as France refrained from inflicting suicidal austerity measures up to now. But with a public debt ratio approaching 110 percent of GDP and a budget deficit of 4.6 percent in 2012 the pressure on France to jump off the fiscal cliff is mounting by the day. Expressing his concern about an apparent "austerity backlash" and threat of "fiscal dominance" in the spring of 2013, Weidmann (2013b) reasserts the old Bundesbank confidence mantra, declaring that "the current crisis is, to a large extent, a crisis of confidence - financial markets have lost their confidence in the sustainability of public finances ... I believe that determined consolidation would help convince the markets that the future fiscal position is going to be sound."

In actual fact, "growth friendly" competitive austerity is only one element in Euroland's strategy to resolve the euro crisis "the German way". Officially growth is also supposed to be generated through courageous structural reform. Liberalizing markets is held to boost Euroland's "growth potential" by raising productivity growth. In practice, "structural reform" is merely a euphemism and code word for measures designed to depress wages. At least this was the German experience with structural reform in the 2000s. There was no miraculous rise in 
productivity growth recorded. Instead, the "sick man of the euro" of the 2000s saw a plunge in investment and sharp rise in inequalities (Hein 2011, 2012).

Growth in productivity and employment presupposes vibrant investment. But neither euro crisis countries nor Euroland at large are investing in the future. Quite the opposite. Public investment is getting crushed by austerity, while private investment continues plunging alongside. Effectively, liberalizing labor markets serves one purpose only: squeezing wages, which is meant to restore competitiveness through internal devaluation. As previously experienced in Germany, rising inequalities undermine any recovery of domestic demand apart from nourishing worsening social and economic instabilities. The IMF has moved away from the "Washington Consensus" and has become alert to links between inequalities and economic stability and growth (see Lagarde 2013), but the "Berlin-Brussels-Frankfurt Consensus" is being pushed to ever-new excesses.

With domestic demand getting systematically chocked, are exports doing the trick then? As Figure 31 highlights, sizeable growth contributions from net exports have markedly contained the depth of the ongoing recession. Furthermore, there has been much excitement about shrinking current account imbalances in Euroland since 2008. Apparently shrinking current account deficits of euro crisis countries vindicate that these countries are making good headway in restoring their competitiveness. Perhaps representative of widely-held complacent market views, a J.P. Morgan research brief of late May 2013 declared: "The Euro area adjustment: about halfway there" (Barr and Mackie 2013).

Unfortunately this is largely an illusion. The decline in unit-labor costs and apparent convergence toward the 2-percent norm (and France's actual record), though not the zeropercent standard set by Germany - highlighted in Figure 4 above - is not due to any real pickup in productivity growth, but mainly reflects labor shedding and some success in squeezing nominal wages. ${ }^{18}$ Unless there is a real pickup in productivity growth relative to Germany, which is unlikely to be brought about by choking investment, wages in Spain, Italy, and France will have to decline some $20-25$ percent relative to German wages. With German wages rising at 2 percent or 3 percent at best annually, Germany's euro south partners still have a long way to go.

\footnotetext{
${ }^{18}$ In the case of Ireland compositional effects appear to have played a large role (Central Bank of Ireland 2011).
} 
Reduced current account imbalances largely reflect cyclical rather than structural positions. Exports of Spain, Italy, and France are growing, but at a lower rate than prior to 2008. Current account deficits of Spain and Italy are down because imports got crushed together with the economy (see Figure 32). ${ }^{19}$ Closing the external deficit in this fashion reduces the external financing needs to rolling over existing debts while eliminating the need to attract net external finance. This should reduce vulnerability of euro crisis countries in case of euro breakup. The problem is that closing Spain's external imbalance at a (close to) 30 percent unemployment rate is bound to leave Spain with a gaping hole in its public finances, among other things. France is lagging behind its southern peers in all regards. Wages have not started adjusting. With flat imports and a record current account deficit in 2012, broad-based crushing through growthfriendly austerity cum structural reform is now also awaiting France. (Recall that the attraction of the above euro-south breakup scenario is that the euro-south group is roughly balanced internally while external rebalancing would be achieved through euro depreciation.)

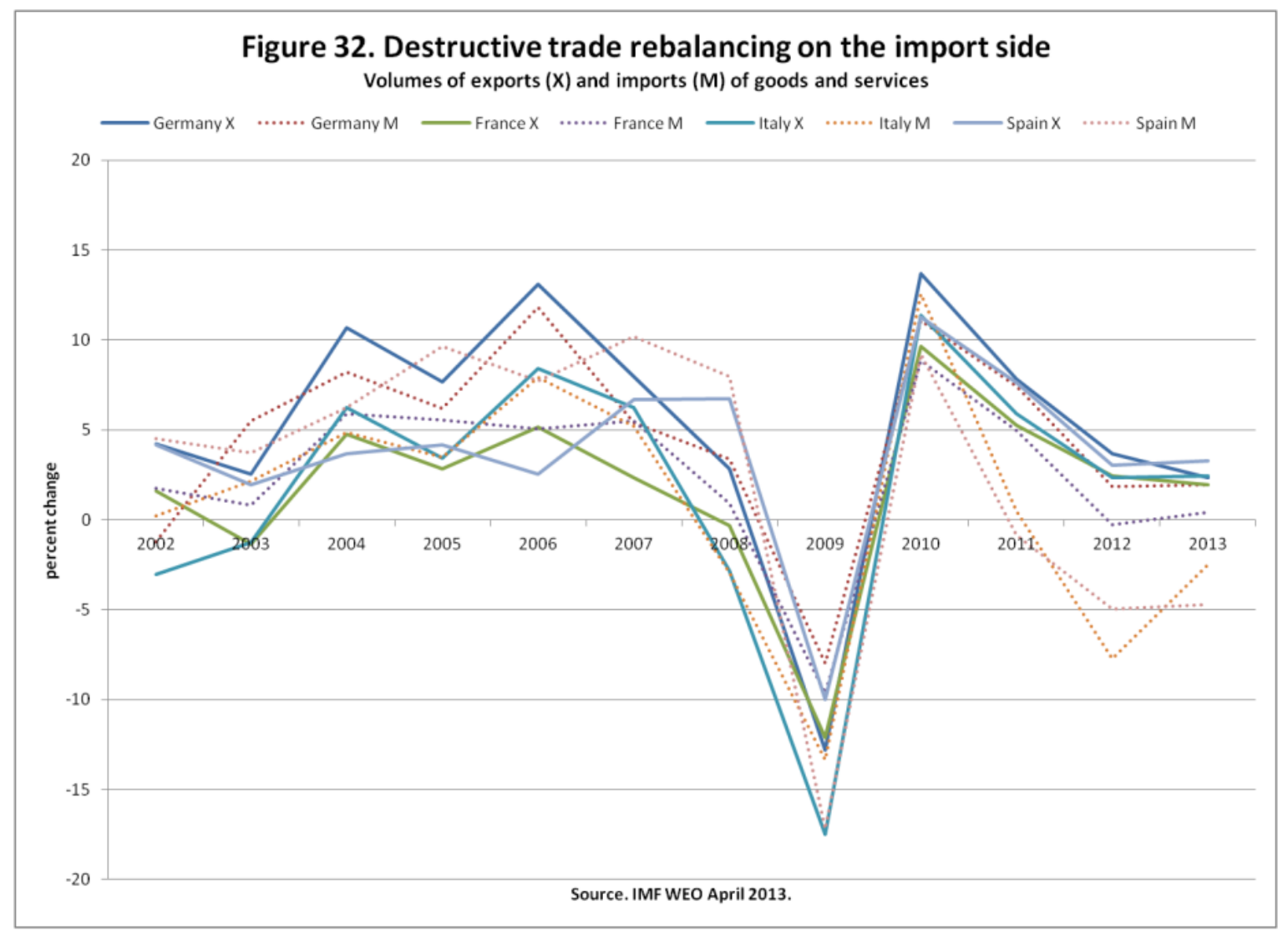

\footnotetext{
${ }^{19}$ While Figure 32 shows growth rates of export and import volumes the OECD's Economic Outlook, Interim Assessment of March 2013 makes the same point by highlighting the collapse in import volumes.
} 
As growth-friendly competitive austerity cum structural reform are - unsurprisingly! proving anything but growth-friendly when pursued simultaneously across Europe, in the end it all boils down to a big bet on rescue by extra-area exports. There is no surprise here either, since that is just the German model applied to Europe. And Germany is calling the shots in the crisis-ridden land of the euro.

In this regard, it therefore deserves emphasizing that any euro policy regime reforms undertaken until now are not of the kind that would actually fix existing regime flaws. They do not remedy the lack of fiscal union and the absence of proper demand management, in particular, but, if anything, have made the system even more rigidly focused on balanced budgets and permanent fiscal austerity. There appears to be absolutely no appreciation of the fact that abstention in these vital areas leaves Euroland at the whim and mercy of external demand. With macro policy chained to price stability cum balanced budgets, focusing policy on competitiveness and relying on exports is just a manifestation of the German view of the world. Mr. Weidmann (2012) said as much when he pointed out last year that only part of Germany's external imbalance was vis-à-vis its euro partners and that rebalancing Euroland would only make that part of the imbalance go away. As seen in Figures 2 and 3 above, from a German perspective, the euro crisis had the convenient side effect of depressing the euro, which boosted Germany’s extra-area current account surpluses.

So beware that by Mr. Weidmann's apparent reasoning, as Germany's euro partners restore their competitiveness, i.e. become equally competitive as Germany, they should also end up running extra-area current account surpluses. Just as Germany balanced its public budget by means of bloated external surpluses, largely vented regionally prior to the euro crisis, today Euroland at large is asked to repeat the exercise at the global level.

In fact, the IMF's (2013) latest World Economic Outlook of April 2013 has all Euroland members and the currency union as a whole running up a large and rising current account surplus position over the projected horizon. A year ago the IMF (2012) estimated that an external surplus position of 1.5 percent of GDP would be "consistent with fundamentals and desirable policies", to which the European Commission (2012, p. 99) happily agreed, declaring that "given its structural characteristics, the euro area should have a moderate current account surplus". Apparently, then, these authorities are agreed that the G-20 Framework for Strong, 
Sustainable, and Balanced Growth agreed at the Pittsburgh Summit in 2009, which commits members to reduce global imbalances and achieve more balanced patterns of global growth, actually permits Euroland to fully embrace German-style mercantilism as its model. But has Euroland really considered how their G-20 partners and the rest of the world, invited to provide the export stimulus needed to make German-style mercantilism work for Euroland, might think about this?

The euro exchange rate is Euroland's vulnerable flank. The German model worked for Germany as long as Germany managed to tie its trade partners to fixed nominal exchange rates (see Figure 1). But the euro exchange rate is neither fixed nor does Euroland have an exchange rate policy. Other countries may not even need to have any explicit exchange rate policy either, as long as their more aggressive monetary policy stance is doing the work. Intellectually trapped and institutionally handicapped, the Buba/ECB is an unlikely winner in the competitive quantitative easing game (aka currency war). The slide of the yen since the fall of 2012 is a case in point here - tightening the screws on Germany and Euroland at large. Freeloading on global growth on a scale as currently exercised by Euroland is bound to provoke currency and trade wars.

These reflections only underline how utterly unsuitable the German model is for Euroland. Succumbing to German monetary mythology, Euroland has done nothing to resolve its crisis. Instead, the Great Euro Deflation is sucking the air out of the global recovery. Euroland would first have to shrink into global irrelevance to pull off the trick it is currently attempting. Meanwhile, the economic consequences of Mrs. Merkel and Mr. Schäuble are piling up for as long as their euro crisis mismanagement continues. So far the collateral damages were felt mainly in the euro crisis countries while only little in Germany itself. But Germany will inevitably catch up with the reality that it is very vulnerable to the enormous wreckage and unnecessary hardship German-style policies are causing across Europe. The EU, most likely under French leadership, will have to convince Germany to settle on a fundamental course change, or else to call an ugly end to the euro disaster (Bibow 2013a, b). 


\section{CONCLUSION: A VULNERABLE SAFE HAVEN}

Relative calm has returned to global financial markets since ECB president Mario Draghi came forth with the promise to do "whatever it takes" to preserve the euro, outlining the prospect of conditional support for government debt markets through "Outright Monetary Transactions". Even the latest Troika bailout of Cyprus in March 2013 did little to disturb the markets' slumber.

But despite some easing in financial conditions underlying realities in euro crisis countries and across Euroland have continued to deteriorate since Mr. Draghi's big bluff won him an important battle in safeguarding the euro. There are two big problems here. First, the conditionality behind Mr. Draghi's promised "unlimited" liquidity support is such as to assure continued debt deflation. Second, ultimately liquidity alone cannot win him the war anyway if fiscal and economic policies remain tuned to killing the patient. ${ }^{20}$ Having first failed in keeping their own house in order and then also in fixing it up after the roof came crashing in on them, Euroland - by foolish choice - remains on global life support, at the mercy of exports to the rest of the world. Reforms undertaken until now have not made the flawed euro policy regime any stronger, but actually weakened the currency union further by sealing its apparent fate as a "Germanized Europe". Yet, the German - essentially neo-mercantilist - model is the wrong model for Europe. The model worked for Germany under peculiar pre-EMU conditions precisely because and as long as others behaved differently. Relative price stability oiled Germany's export engine when its trade partners were locked into fixed nominal exchange rate regimes by boosting German competitiveness. Germany could get away with fiscal austerity when other nations' over-spending enabled Germany to balance its own public budget alongside a gaping external imbalance.

(West) Germany had nourished this tradition since WWII. When the German model was exported to Europe through the Maastricht Treaty, Germany at first got sick. For, quite simply, a model the workability of which depends on others behaving differently from Germany cannot be made to work by forcing everyone to behave just like Germany. Hence, as Europe converged to the German stability norm, the German model stopped working in its home country, and

\footnotetext{
${ }^{20}$ A quantitative limit arises indirectly through the ECB's declared self-restriction to intervene in debt securities traded in markets of maturities of one to three years only. See ECB (2012) and Schorkopf (2012).
} 
Germany became the "sick man of the euro". After first getting sick under the euro as a result, Germany then underbid its partners to cure itself. So the very threat which the euro was designed to ban forever undermined the currency union: competitive devaluation, albeit through wages rather than the nominal exchange rate. What amounted to "beggar-thy-neighbor" German wage repression laid the groundwork for the ongoing euro crisis.

If Germany did itself a disfavor by exporting its model to Europe, it made matters far worse for itself by trying to resurrect a national version of that model inside the currency union. Ironically, despite its adamant opposition to a European "transfer union", Germany has maneuvered itself into its own "euro trilemma" of that very kind. For Germany "cannot have all three: perpetual export surpluses, a no transfer/no bailout monetary union, and a "clean" independent central bank" (Bibow 2012a).

By running up large current account surpluses, which prior to the euro crisis were concentrated in Europe, both in terms of trade flows and in terms of their financial counterpart, Germany made itself highly vulnerable to deteriorating conditions in its euro partner countries. Germany may have successfully re-loaded and re-sourced its current account surplus from outside the currency union and continues to enjoy safe-haven status, but its external creditor position remains subject to large losses in case of euro breakup. Even as Germany's banking system may have greatly cut its exposure, other remaining risks are concentrated on the Bundesbank's balance sheet and the balance sheets of nonbank financial intermediaries. Apart from wealth losses, Germany would get hit by an abrupt loss in competitiveness as a new deutschmark would likely see a sharp appreciation in case of a euro breakup.

The matter seems to boil down to a choice between the following two options. Either Euroland continues along the current path which has Germany with a public debt ratio stabilized around 80 percent of GDP and enjoying its international creditor position, for the time being at least, while euro-south countries see their public debt ratio surge beyond 120 percent of GDP, left without any chance to relieve their external debt position unless the rest of the world volunteers to provide external growth stimuli and shoulder the debt instead. Or break up the euro to bring immediate debt relief and a swift restoration of competitiveness to the euro south, so as to rekindle growth there, in which case Germany would see much of its NIIP evaporate 
and its public debt ratio surge toward or beyond 120 percent of GDP, along with mass unemployment.

So Germany has a lot to gain from avoiding a euro breakup, which should open up a third option. The third option is to fix the flawed Maastricht regime and deal with the rebalancing and debt legacy challenges in a more equitable fashion. The supposed safe haven Germany is very vulnerable. If they mustered the leadership, Germany's euro partners should be in a position to force about the needed U-turn in Euroland policymaking and end policies that have pushed the currency union and the peoples of Europe to the brink of disaster. The German model is wrong for Europe. Trash it or break up the currency union. 


\section{REFERENCES}

Atkins, R. and K. Fray, K. (2013). "Eurozone Banks Cut Cross-Border Debt Holdings."

Financial Times, June 10. http://www.ft.com/intl/cms/s/0/33429faa-cec4-11e2-8e1600144feab7de.html\#axzz2WfbiolFX

Athanassio, P. (2009). "Withdrawal and Expulsion from the EU and EMU: Some Reflections." ECB, Legal Working Paper, No. 10, December. http://www.ecb.int/pub/pdf/scplps/ecblwp10.pdf

Atkins, R. (2010). “Germany Attacks U.S. Economic Policy.” Financial Times, November 7.

Avdjiev, S., Z. Kuti., and E. Takáts. (2012). "The Euro Area Crisis and Cross-border Bank Lending to Emerging Markets.” BIS, Quarterly Review, December, pp. 37-47.

Barber, L., Q. Peel, and G. Wiesmann. (2010). "Merkel Warns of Protectionism.” Financial Times, 8 November.

Barr, M. and D. Mackie. 2013. “The Euro Area Adjustment: About Halfway There.” J.P. Morgan, Europe Economic Research, 28 May.

Berentsen, A., A. Marchesiani and C.J. Waller. (2013). "Floor Systems for Implementing Monetary Policy: Some Unpleasant Fiscal Arithmetic.” University of Zurich, Department of Economics, Working Paper 121, May. http://ideas.repec.org/p/zur/econwp/121.html

Bibow, J. (2005). "Germany in Crisis - The Unification Challenge, Macroeconomic Policy Shocks and Traditions, and EMU." International Review of Applied Economics, 19(1): $29-50$.

_. (2006) "The Euro Area Drifting Apart - Does Reform of Labor Markets Deliver Competitive Stability or Competitive Divergence?" In Structural Reforms and MacroEconomic Policy, European Trade Union Confederation, 76-86.

_ (2009) "The American-German Divide: Macro Policy and International Co-operation." New America Foundation, New American Contract Policy Paper, July 8.

- (2010). Comment: German Exports Are Fine but Perpetual Export Surpluses Are Not, The Economist debates Germany, The Economist, 10 April. https://www.economist.com/user/3660236/comments . (2012a). "The Euro and Its Guardian of Stability: Fiction and Reality of the 10th Anniversary Blast." In Monetary Policy and Central Banking: New Directions in PostKeynesian Theory, edited by L.-P. Rochone and Salewa 'Yinka Olawoye. Cheltenham, U.K. and Northampton, MA, U.S., Edward Elgar, pp. 190-226. (Working Paper No. 583. Annandale-on-Hudson, NY: Levy Economics Institute of Bard College.)

_ (2012b). "The Euroland Crisis and Germany's Euro Trilemma", International Review of Applied Economics Online. (Working Paper No. 721. Annandale-on-Hudson, NY: Levy Economics Institute of Bard College.) 
. (2013a). "At the Crossroads: The Euro and Its Central Bank Guardian (and Savior?). Cambridge Journal of Economics, 37(3): 609-26. (Working Paper No. 738, November 2012. Annandale-on-Hudson, NY: Levy Economics Institute of Bard College.)

. (2013b). On the Franco-German Euro Contradiction and Ultimate Euro Battleground." Working Paper No. 762, April. Annandale-on-Hudson, NY: Levy Economics Institute of Bard College Forthcoming in Contributions to Political Economy.

Bootle, R. (2012). "Leaving the Euro: A Practical Guide." Capital Economics, https://www.capitaleconomics.com/data/pdf/wolfson-prize-submission.pdf

Bundesbank (2008). “Germany's International Investment Position since the Beginning of Monetary Union: Developments and Structure.” Monthly Bulletin, October, 15-32.

—. (2009). “German Enterprises' Profitability and Financing in 2007.” Monthly Bulletin, January, 31-53.

—_. (2011). “Germany's Balance of Payments in 2010.” Monthly Bulletin, March: 17-36.

—. (2012). “Germany's Balance of Payments in 2011.” Monthly Bulletin, March: 15-33.

—. (2013). “Germany’s Balance of Payments in 2012.” Monthly Bulletin, March, 15-28.

Burda, M. (2012). “Hume on Hold?” Vox EU, 17 May. http://www.voxeu.org/article/hume-holdconsequences-not-abolishing-eurozone-national-central-banks

Cecchetti, S., R.N. McCauley, and P.M. McGuire. (2012). “Interpreting TARGET2 Balances.” BIS Working Paper No. 393, December.

Central Bank of Ireland (2011). "Compositional Effects in Recent Trends in Irish Unit Labour Costs.” Quarterly Bulletin, January.

Cesaratto, S. (2011). "Notes on Europe, German Mercantilism and the Current Crisis." In The Global Economic Crisis: New Perspectives on the Critique of Economic Theory and Policy, edited by E. Brancaccio, G. Fontana, 246-60. London and New York: Routledge.

Chen, R., G.-M. Milesi-Ferretti, and T. Tressel. (2012). "External Imbalances and the Euro Area.” IMF Working Paper WP/12/236, Economic Policy, http://onlinelibrary.wiley.com/doi/10.1111/1468-0327.12004/pdf

Cliffe, M. , P. van den Houte, and M. van Vliet. (2012). "EMU: Fixing It Is Far Cheaper Than Breaking It.” IMF, Financial Markets Research, 16 August.

De Grauwe, P. and Y. Ji. (2012). "What Germany Should Fear Most Is Its Own Fear." VoxEU.org. 18 September.

Deo, S., P. Donovan, and L. Hatheway (2011). "Euro Break-up - The Consequences." UBS, Global Economic Perspectives, September 6.

European Banking Authority (2011). "European Banking Authority 2011 EU-Wide Stress Test Aggregate Report.” 15 July. 
http://eba.europa.eu/documents/10180/15935/EBA_ST_2011_Summary_Report_v6.pdf/ 54a9ec8e-3a44-449f-9a5f-e820cc2c2f0a

European Central Bank (2012). “Technical Features of Outright Monetary Transactions, Press Release, September 6, http://www.ecb.int/press/pr/date/2012/html/pr120906_1.en.html

European Commission (2012). "Current Account Surpluses in the EU." European Economy 9/2012.

http://ec.europa.eu/economy_finance/publications/european_economy/2012/pdf/ee-20129_en.pdf

Flassbeck, H. (2007). "Wage Divergences in Euroland: Explosive in the Making." In Euroland and the World Economy - Global Player or Global Drag?, edited by J. Bibow and A. Terzi. Palgrave Macmillan.

Hein, E. (2011). "Financialization, Re-distribution, and the Financial and Economic Crisis: A Kaleckian Perspective" In Stabilizing an Unequal Economy? Public Debt, Financial Regulation, and Income Distribution, edited by T. Niechoj, Ö. Onaran, E. Stockhammer, A. Truger, and T. van Treeck, 35-62. Marburg: Metropolis.

. (2012). "The Crisis of Finance-Dominated Capitalism in the Euro Area, Deficiencies in the Economic Policy Architecture, and Deflationary Stagnation Policies." Working Paper No. 734. Annandale-on-Hudson, NY: Levy Economics Institute of Bard College.

Houlder, V. (2013). "Figures Shed Light on Tax Avoidance Haul.” FT.com, 30 April.

IMF (2011) “Germany: Technical Note on Banking Sector Structure.” IMF Country Report No. 11/370, December http://www.imf.org/external/pubs/ft/scr/2011/cr11370.pdf

_. (2012). "Pilot External Sector Report." Washington, D.C.

Lagarde, C. (2013). "Stability and Growth for Poverty Reduction.” Speech, Washington DC, 15 May. http://www.imf.org/external/np/speeches/2013/051513.htm

OECD (2013). “Economic Outlook, Interim Assessment.” March, Paris.

Reinhart, C. and K. Rogoff. (2011). This Time Is Different: Eight Centuries of Financial Folly, Princeton, Princeton University Press.

Rose, A.K. (2007). "Checking Out: Exits from Currency Unions.” Monetary Authority of Singapore, Staff Paper No. 44, April. http://www.mas.gov.sg/About-MAS/Monographs-andinformation-papers/Staff-

Papers/2007/ /media/resource/publications/staff_papers/StaffPaper44Rose.ashx

Schorkopf, F. (2013). Statement to the German Constitutional Court, January, http://www.handelsblatt.com/downloads/8135244/3/EZB\%20Gutachten

Schumacher, D., and M. Dourmaguet. (2013)." The High Costs of a Euro Break-Up for Germany." Goldman Sachs, European Economics Analyst, No. 13/07.

Schuman, R. (1950). Schuman Declaration, 9 May. 
Sinn, H.-W. and H. Feist. (1997). "Eurowinners and Eurolosers: The Redistribution of Seigniorage Wealth in EMU." European Journal of Political Economy 13: 665-89. http://www.cesifo-group.de/portal/page/portal/ifoContent/N/rts/rtsmitarbeiter/IFOMITARBSINNCV/CVSinnPDF/CVSinnPDFrefjournalsbis2006/EUROWINNERS.pdf

Sinn, H.W. (2007). “The 30 Billion Euro Deal.” Vox EU, 22 June. http://www.voxeu.org/article/30-billion-euro-deal

Sinn, H.W., and T. Wollmershuser. (2012). "TARGET Loans, Current Account Balances and Capital Flows: The ECB's Rescue Facility.” NBER Working Paper No. 17626, November.

Soros, G. 2012. "The Tragedy of the EU and How to Resolve It." The New York Review of Books, September 27.

Statistisches Bundesamt (2013). Wirtschaft und Statistik, January, p. 22. . (2013). Vermerk: Aussenhandel/VGR, 3 April.

UNCTAD (2010). "Trade and Development Report: Employment, Globalization and Development." Geneva.

Van Rixtel, A. and N. Vause. (2012a). "Highlights of the BIS International Statistics." Bank for International Settlements, Quarterly Review, June, 11-24.

Van Rixtel, A. and C. Upper. (2012b). "Highlights of the BIS International Statistics." Bank for International Settlements, Quarterly Review, December, 11-22.

Van Rixtel, A., N. Vause, and C. Upper. (2013). "Highlights of the BIS International Statistics." Bank for International Settlements, Quarterly Review, June, 13-23.

Vause, N., G. von Peter, M. Drehmann, and V. Sushko. (2012). "European Bank Funding and Deleveraging." Bank for International Settlements, Quarterly Review, March, 1-12.

Wallich, H.C. (1955). Triebkrafte des deutschen Wiederaufstiegs. Frankfurt am Main, F. Knapp.

Wallich, H.C. and Wilson, J.F. (1979). "Thirty Years (almost) of German Surpluses." Zeitschrift für die gesamte Staatswissenschaft, Vol. 135 (2): 480-92.

Weidmann, J. (2012). “Rebalancing Europe.” Speech, London, March 28, BIS Central Bankers' Speeches. http://www.bis.org/review/r120329a.pdf

_ . (2013a). "Crisis Management and Regulatory Policy." Speech at the Walter Eucken Institute, Freiburg, February 11. http://www.bis.org/review/r130214c.pdf

—. (2013b). "Who calls the shots? The Problem of Fiscal Dominance." Speech, Paris, BIS Central Bankers' Speeches, May 24. http://www.bis.org/review/r130524d.pdf

Whelan, K. (2012). "TARGET2 and Central Bank Balance Sheets." UCD Center for Economic Research, Working Paper 12/29, November (revised March 2013). 
Wiesmann, G. and S. Pignal. (2010). "Germany Hits Back at French and U.S. Criticism." Financial Times, October 21. 